\title{
Fish, food security and health in Pacific Island countries and territories: a systematic literature review
}

\author{
Karen E. Charlton ${ }^{1 *}$, Joanna Russell ${ }^{2}$, Emma Gorman $^{2}$, Quentin Hanich ${ }^{3}$, Aurélie Delisle ${ }^{3}$, Brooke Campbell ${ }^{3}$
} and Johann Bell ${ }^{3,4}$

\begin{abstract}
Background: Pacific Island countries and territories (PICTs) face a double burden of disease, with a high prevalence of household food insecurity and childhood micronutrient deficiencies, accompanied by a burgeoning increase in adult obesity, diabetes and heart disease.

Methods: A systematic literature review was undertaken to assess whether increased availability of, and access to, fish improves a) household food security and b) individual nutritional status.

Results: A total of 29 studies were reviewed. Fourteen studies identified fish as the primary food source for Pacific Islanders and five studies reported fish/seafood as the primary source of dietary protein. Fish consumption varied by cultural sub-region and Pacific Island countries and territories. Fish consumption and nutritional status was addressed in nine studies, reporting moderate iodine deficiency in Vanuatu where only $30 \%$ of participants consumed mostly fresh fish. Similarly, the degree to which Pacific Islanders depended on fishing for household income and livelihood varied between and within PICTs. For more economically developed countries, household income was derived increasingly from salaried work and dependency on fishing activities has been declining.

Conclusions: Fishing remains a major contributor to food security in PICTs, through subsistence production and income generation. However, there is a paucity of research aimed at assessing how maintaining and/or improving fish consumption benefits the diets and health of Pacific Islanders as they contend with the ongoing nutrition transition that is characterised by an increasing demand for packaged imported foods, such as canned meats, instant noodles, cereals, rice, and sugar-sweetened beverages, with subsequent decreased consumption of locally-produced plants and animals.
\end{abstract}

Keywords: Pacific Islands, Food security, Fish, Systematic review, Non communicable diseases

\section{Background}

The Pacific Island region comprises 22 countries and territories which are diverse in geography, population size, culture and economy. Melanesian island countries (Table 1) are typically large and mountainous with fertile soils, whereas the smaller Polynesian and Micronesian islands (Table 1) are either volcanic areas or low lying coral atolls [1]. Population sizes vary from as little as 1,200 in Tokelau, the smallest Pacific Island territory to

\footnotetext{
*Correspondence: karenc@uow.edu.au

${ }^{1}$ School of Medicine, University of Wollongong, Wollongong, NSW 2522, Australia

Full list of author information is available at the end of the article
}

7.4 million in Papua New Guinea, the largest Pacific Island country [2]. GDP per capita is low in most Pacific Island countries and territories (PICTs), ranging from US\$1,651 in Kiribati to US\$36,405 in New Caledonia [3] with five PICTs (Kiribati, Samoa, Solomon Islands, Tuvalu and Vanuatu) currently classified as Least Developed Countries [1, 4].

The nutrition transition [5] is well underway in PICTs. Dietary patterns have shifted since the 1970-80s from reliance on traditional low fat diets, typically based on complex carbohydrates, fresh fish and meat and leafy greens, to increasingly modern diets, based on refined starch, oils, processed meats and confectionary [6-10]. 
Table 1 Pacific Island countries and territories

\begin{tabular}{lll}
\hline Melanesian & Polynesian & Micronesian \\
\hline Fiji & American Samoa & Federated States of Micronesia \\
New Caledonia & Cook Islands & Guam \\
Papua New Guinea & French Polynesia & Kiribati \\
Solomon Islands & Niue & Marshall Islands \\
Vanuatu & Pitcairn Island & Nauru \\
& Samoa & Northern Marianas Islands \\
& Tonga & Palau \\
& Tokelau & \\
& Tuvalu & \\
& Wallis and Futuna &
\end{tabular}

This relatively rapid transition in the Pacific Island region has resulted in an increasing demand for packaged imported foods, such as canned meats, instant noodles, cereals, rice, and sugar-sweetened beverages, with subsequent decreased consumption of locally-produced plants and animals, leading to high vulnerability to food insecurity [11]. Moreover, such diets have been identified as a major contributor to the double burden of communicable and non communicable diseases (NCDs) in the region $[6,12]$. NCDs now account for between 60 and $80 \%$ of all deaths in the region $[13,14]$ and the prevalence of diabetes and obesity are among the highest in the world [15]. At the same time, the incidence of malnutrition and vitamin and mineral deficiencies continue to be major public health concerns [16, 17]. Iron-deficiency anaemia, which is associated with impaired cognitive and motor development, low birth weight and prematurity [18, 19], affects up to $57 \%$ of the population in some PICTs (mostly children and women) [20]. As has been reported in other low-income countries [21-26], it is not uncommon to find both malnourished children and overweight/obese adults co-residing in the same household [12].

Food security, defined as the physical, social and economic ability to access sufficient, safe and nutritious food, is already identified as under threat in many PICTs due to the dietary shifts caused by changes in population growth, urbanisation and climate [1, 27]. It is evident that significant economic, environmental and population health reforms will be required to ensure that Pacific Island populations have reliable sources of affordable and nutritious food in the future [28].

Across the globe, fish and fisheries have been identified as being a crucial element in achieving food security, particularly in less-developed countries $[29,30]$. In the Pacific Island region, the major contribution of fisheries to livelihoods, revenue and development is undisputed. Fish contribute substantially to both the subsistence and market-based economies of PICTs, and national rates of fish consumption are among the highest in the world [27]. It is acknowledged that increased fish supplies are needed to meet growing food security demands [31]. However, there is a lack of information regarding the contribution of fish consumption to overall nutritional adequacy and health status in PICT populations.

Here, we report the findings of a systematic literature review undertaken to explore how availability of fresh fish affects the nutritional status of Pacific Island populations. The review considered both direct benefits of fish consumption to nutritional status, as well as indirect benefits to nutritional status and food security resulting from improvements in livelihoods related to fishing.

\section{Methods}

The following PICO (participants, interventions, comparisons and outcomes) question formed the basis for the systematic literature review: Among Pacific Islanders, does increased availability of and/or access to fish, compared to reduced availability or access, improve a) household food security and b) individual nutritional status? Depending on individual study designs, relative availability or access to fish was compared between communities or provinces within a single country, or between countries and/or the three Pacific sub-regions. In the case of studies conducted over different time periods, this was also analysed as change over time. For the purpose of this review, household food security is used in the context of either an individual within a household or a household comprising more than a single person. In relation to nutritional status, the influence of fish consumption on both under and over-nutrition was considered. Pacific Islanders were defined as individuals residing in the following PICTs: Commonwealth of the Northern Mariana Islands, Cook Islands, Federated States of Micronesia, Fiji, French Polynesia, Guam, Kiribati, Marshall Islands, Nauru, New Caledonia, Niue, Palau, Papua New Guinea, Pitcairn Island, Samoa, American Samoa, Solomon Islands, Tokelau, Tonga, Tuvalu, Vanuatu and Wallis and Futuna.

In December 2014, systematic searches were conducted using three major online academic literature databases. The Scopus database was searched using varying combinations of keywords, as listed in Table 2. Seven separate searches were conducted, with no new relevant articles being identified after search four. Additional searches were conducted in Web of Science and Medline databases using the same search strategy.

Articles from the peer-reviewed literature in English published between 2004 and December 2014 were eligible for inclusion if they addressed either fish consumption amongst Pacific Islanders and/or the contribution of fishing activities to the livelihoods of Pacific Island people. Fish consumption could include either fresh or canned fish. Fishing activities could relate to both commercial and 
Table 2 Search terms used to identify articles for review

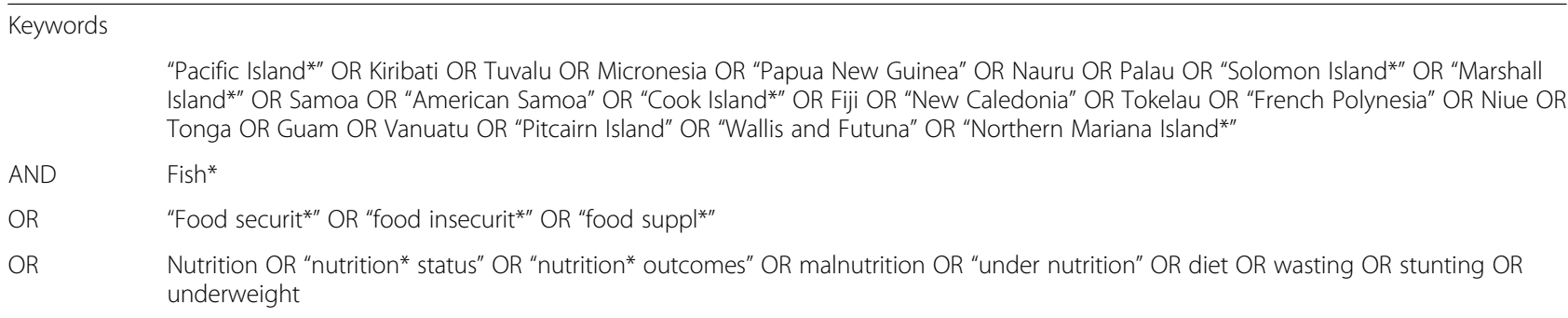

*denotes that any word preceded by this term could be included as a search term

subsistence practices. Exclusion criteria were: review articles, studies focused on historical fish consumption in PICT communities, studies of institutionalised individuals, studies focused on the contribution of the fishing industry to a country's national revenue or gross domestic product and studies describing fishing and fisheries, such as annual fish catch, that did not relate the activity to income generation or provision of subsistence.

As a broad range of search terms were needed to identify articles relevant to both nutrition and food security, the initial database search returned a large number of records. To remove subject areas irrelevant to the review, exclusions were made using database functions (Table 3). Records were exported to EndNote version X7 and duplicates removed. A title and abstract search was carried out to screen records against the inclusion and exclusion criteria. Eligibility of any remaining articles was determined through a full text assessment. Where there were aspects of doubt over a study's eligibility, the

Table 3 Subject areas excluded using database functions

\begin{tabular}{|c|c|c|}
\hline Scopus & Web of Science & Medline \\
\hline Neuroscience & Parasitology & \multirow{13}{*}{$\begin{array}{l}\text { Function not } \\
\text { available }\end{array}$} \\
\hline Psychology & Toxicology & \\
\hline Computer science & Infectious diseases & \\
\hline Dentistry & $\begin{array}{l}\text { Pharmacology and } \\
\text { pharmacy }\end{array}$ & \\
\hline Chemical engineering & $\begin{array}{l}\text { Nuclear science } \\
\text { technology }\end{array}$ & \\
\hline Engineering & Clinical neurology & \\
\hline Mathematics & Neurosciences & \\
\hline Material sciences & Surgery & \\
\hline \multirow{5}{*}{$\begin{array}{l}\text { Physics and astronomy } \\
\text { Pharmacology, toxicology } \\
\text { and pharmaceutics }\end{array}$} & $\begin{array}{l}\text { Medicine research } \\
\text { experimental }\end{array}$ & \\
\hline & $\begin{array}{l}\text { Engineering chemical } \\
\text { Virology }\end{array}$ & \\
\hline & $\begin{array}{l}\text { Computer science } \\
\text { interdisciplinary applications }\end{array}$ & \\
\hline & $\begin{array}{l}\text { Radiology nuclear medicine } \\
\text { medical imaging }\end{array}$ & \\
\hline & $\begin{array}{l}\text { Operations research } \\
\text { management science }\end{array}$ & \\
\hline
\end{tabular}

investigator conducting the search (EG) sought a second and third opinion from other members of the research team. The review followed the PRISMA guidelines [32] for reporting systematic literature reviews.

Online resources, including the websites of the Food and Agricultural Organisation (FAO), the World Health Organisation (WHO), the World Bank, WorldFish, the Secretariat of the Pacific Community and the United Nations International Children's Emergency Fund were also searched using the same approach to identify relevant grey literature.

Additionally, one country from each of the three cultural sub-regions within the Pacific Islands was examined in more detail to identify economic, demographic and health differences among sub-regions. These islands were Vanuatu in Melanesia, Kiribati in Micronesia and Tonga in Polynesia.

\section{Results}

A total of 31 articles were identified for inclusion in the final review (Fig. 1). In two instances, two articles described results from the same study [33-36], and all four articles were included in this review. The findings are summarised, by country, according to two themes, fish consumption (shown in Table 4) (33-55, 57-59), and contribution of fishing to household income (shown in Table 5) (37, 42, 43, 45, 60-64). In addition, the three sub-regional case studies are described in Tables 6, 7 and 8. Only relevant papers identified using the defined search strategy are cited in the tables whereas additional sources of information are included in the Discussion.

\section{Fish consumption Fish intake in Pacific Islanders}

Fish was identified as a primary food source for Pacific Islanders in 15 studies [36-50] although the amount and type of fish consumed varied based on factors such as geographical location and socio-economic status. The following section describes the patterns in Pacific Island fish intake reported in these studies. 


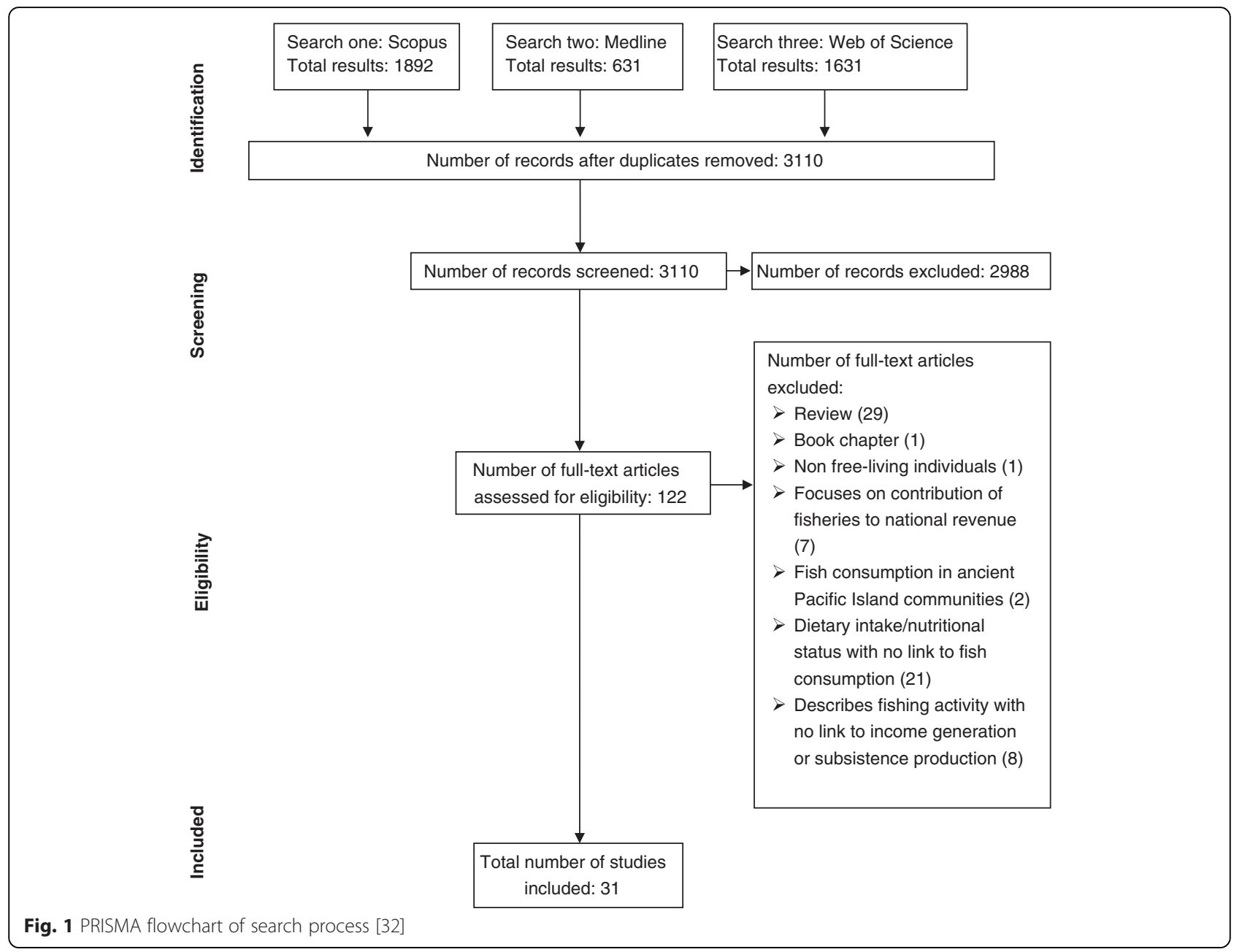

\section{American Samoa}

A study of subsistence fishing practices in two outer islands of American Samoa found that $89 \%$ of the fish harvest was consumed locally, with the remainder being sent to family members on other islands. Interviews with local elders suggested that fishing activities had not changed much over their lifetime and that there were ample fish resources still available [47].

\section{Federated States of Micronesia}

In Pohnpei, an island in the Federated States of Micronesia (FSM), $79 \%$ of adults reported frequent consumption of fresh fish and/or seafood with locallycaught fresh fish and/or seafood consumed 4.8 days/ week compared to 2.4 days/week for imported fish and/ or seafood, including canned fish [37]. This contrasts to results from the Health Behaviour and Lifestyle of Pacific Youth study (HBLPY), which reported that fresh fish was consumed by only $42 \%$ of 15 -year-old students at seven schools in Pohnpei, whereas there was high consumption of processed foods such as canned meat and carbonated beverages [40].

Fiji

Fish intake in Fiji was assessed by Kuster et al.[45] and Turner et al. [42]. In a comparison of subsistence fishing patterns between 1982 and 2002 on Ono-i-Lau Island, Kuster et al.[45] found that fresh fish remained the main source of dietary protein (finfish $261 \mathrm{~g} \pm$ 90/person/day in 1982 and $269 \mathrm{~g} \pm 100$ /person/day in 2002) for villagers over a 20 year time span. Consumption of tinned fish doubled from $9 \mathrm{~g}$ per person per day to $19 \mathrm{~g}$ per person per day over the same period. In the remote Lau islands, local fishers and senior heads of households reported the frequency of consuming fresh fish had declined over the previous 10 years to an average current consumption level of three days per week. The decline in frequency of fish consumption was associated with higher household income. In Naikeleyaga, the Lau island village with the highest annual household income, participants reported the frequency of fish consumption declined from four to 
Table 4 Characteristics and main findings of studies assessing fish consumption ${ }^{a}$

Reference Population Design ${ }^{\mathrm{b}}$

Melanesia

Fiji

Hedges et al.

[54]

20 non-pregnant

non nursing females

in Verata

Kuster et al. [45]

Ono-i-Lau Island30

senior heads of

households in

198259 households

in 2002

heads of households

New Caledonia

Guillemot et al.

[44]

Labrosse et al. [50]
Cross sectional study :

a) Food records - food

over two $\mathrm{x}$ weekly periods,

3 weeks apart

Cross sectional

Cross sectiona

Semi structured

face-to-face interviews and beverages consumed

Outcome measures

Key findings $s^{b}$
Energy derived from

protein, fat and carbohydrate

(CHO), intake of protein and sources of protein intake

Mean energy from protein/carbohydrate/ fat over the 2 weeks was $13 \% / 66 \% / 21 \%$ respectively.Mean intake of energy was

$9080 \mathrm{KJ} /$ day.

Mean intake of protein was $70.6 \mathrm{~g}$

Primary sources of protein were cereals

$3.7 \%$ of protein energy) followed by

ish (3.4\%), meat (1.7\%) and shell

fish (1.5\%). Higher consumption of

marine foods was associated with

ower cereal intake $(-0.54)$.

Mean weekly household income Total annual landings of finfish and fish yield per capital. Daily fish intake per capita (g) and contribution of marine sources to protein intake. decreased by $27 \%$ from 1982 to 2002

No significant change in yield of finfish per capita of population (96.9 kg per capita/year in 1982 to $93.7 \mathrm{~kg}$ capita/year in 2002) Seafood remained the main source of protein between 1982 and 2002.

Consumption of canned

fish increased from 9 $\mathrm{g} / \mathrm{man} /$ day to $19 \mathrm{~g} / \mathrm{man} /$ day

Time spent fishing, importance No significant change in overall time of fishing for income generation, spent fishing in the past 6-10 patterns of fish consumption and years.Income-generating activities had awareness of ecological change increased in importance over previous 10 within the local qoliqoli years relative to fishing activities Consumption (fishing ground) of fresh fish was significantly lower compared to estimates of past consumption $(Z=-3.774$ $p<0.001)$.

Greatest decline in fish consumption was associated with highest mean household income.Of the $80-100 \%$ of households that engaged in fishing, only $7 \%$ of

households ranked fishing as the primary household occupation.

Average number of fishing trips per year, average catch per fishing trip $(\mathrm{kg})$ and annua reef fish consumption per capita

Total catches of reef fish estimated at 169 t/year.7720 fishing trips made/year. Mean catch per fishing trip per boat was $23 \mathrm{~kg}$.Annual reef fish consumption estimated at $18 \mathrm{~kg} /$ person/year the North west coast 
Table 4 Characteristics and main findings of studies assessing fish consumption ${ }^{\text {a }}$ (Continued)

\section{aged \\ over 7 years, in the \\ Face-to-face 13-item}

Northern Province

38 households on

Ouvea Island

[48]

Solomon Islands

Aswani \& Furusawa

[52]

Mertz et al.

[41]

46 heads of households

in Tikopia

Papua New Guinea

van der Heijden

[57]

609 individuals residing in

high, middle and low altitude

villages in the Ramu catchment

and 204 fishers from the Yonk

Reservoir (high altitude)
Cross sectional

Face-to-face household

questionnaire

Cross sectional study:

Structured face-to-face

interviews questionnaire

Weekly and annual fish intake, quantity of fish versus purchased fish intake

Cross sectional study:

Face-to-face household

questionnaire

Annual fish consumption

per household and per

consumption unit (CU)

Contribution of marine resources to protein $i$ ntakeEnergy (MJ)

Face-to-face semi-structured interviews, $24 \mathrm{~h}$ dietary recall Anthropometric assessment

and $1 \mathrm{~h}$ dietary recall questionnaire
Cross sectional study:Face-to-face 39-item FFQ (foods were classified as 'traditional foods' or 'store foods') per meal (g), subsistence
Contribution of fish to intake of anima based foods
Only $1.3 \%$ of the participants reported never eating fish. $85 \%$ of participants ate fish 1 or more times a week, with $45 \%$ of these eating fish $2-3$ times/week and $11 \%$ consuming fish 1-2/day.Average weekly consumption of fish was 4.8 meals \pm 0.7 .

Average quantity of fish consumed at a meal was $233 \mathrm{~g} \pm 16 \mathrm{~g} .92 \%$ percent of annual fish consumption was classified as subsistence with only $8 \%$ purchased.

Annual fish consumption per household was a mean $289 \mathrm{~kg}$.Mean fish consumption per CU was $63 \mathrm{~kg} \pm 9.7 \mathrm{~kg}(\mathrm{SD})$. Subsistence production was the main source of supply of fish for two thirds of households, followed by gifts and purchases from the market.

$64-100 \%$ of all participants identified fish as the main source of protein consumed by their householdMales and females consumed a sufficient amoun of protein according to the FAO/WHO/UNU reference values 1985.Between 2001 and 2005 mean energy intake in both males $(P<0.01)$ and females $(P<0.0001)$ increased. There were no statistically significant changes in BMl for either males or females between 2001 and 2005.

Fish consumed daily by $72 \%$ of households. Main source of dietary protein was fish Imported canned fish and meat were eaten when available, but was rarely available.

Fish and other aquatic animals caught in nearby waters contributed $7.7 \%$ of food from animal sources for high and middle altitude participants.Fish was the most important source of animal protein for low altitude respondents ( $41 \%$ of all food from animal sources) and the second most important source for respondents at Yonki Reservoir ( $25 \%$ of all food from animal sources).Canned fish and lamb flaps were the most commonly purchased animal foods

"Socio-economic index" was positively correlated with greater consumption of socio-economic status and food intake type 
Table 4 Characteristics and main findings of studies assessing fish consumption ${ }^{\mathrm{a}}$ (Continued)

Republic of Vanuatu

Dancause et al.

[46]

425 children and 559 adults on three islands varying in economic development

(Ambae, Aneityum and Efate)

Cross sectional study: Face-to-face behavioural questionnaire24 $\mathrm{h}$ dietary recall
Identification of key dietary patterns Association between dietary pattern and BMI $\left(\mathrm{kg} / \mathrm{m}^{2}\right)$ and blood pressure $(\mathrm{mm} \mathrm{Hg})$

Anthropometic dietary patterns

ometric assessment

$(\mathrm{kg})$, and blood pressure (BP)
Behavourial changes

within and among islands associated with economic development
Association between fish and meat intake and anthropometric measures

534 males and females aged $\geq 18$ years on three islands: Ambae, Aneityum and Efate

fruits and vegetables compared to

"store foods" e.g., rice, noodles, canned

fish and soft drink $(P=0.04)$

Two dietary patterns emerged. 'Traditional diet' - which was correlated with consumption of bananas, tubers, other sweet potato, pawpaw and leafy greens and negatively correlated with consumption of rice, canned fish and soft drinks. The second dietary

pattern was correlated with consumption of store bought foods e.g., rice, noodles, canned fish and soft drinksMedian BMI was 27 in females and 29 in males. $38 \%$ of females and $23 \%$ of males classified as obese (BMI $\geq 30)$. Systolic BP was > than $140 \mathrm{~mm} \mathrm{Hg}$ in $8 \%$ of females and $19 \%$ of malesDiastolic BP was > than $90 \mathrm{~mm} \mathrm{Hg}$ in $10 \%$ of females and $13 \%$ of males.No association was found between cardiovascular risk factors (BMI and $\mathrm{BP}$ ) and dietary patterns

Hypertension or CVD among family members was reported by $19.7 \%$ of participants in Ambae, by $35.3 \%$ in Aneityum and $45.1 \%$ in Efate.

Overweight and obesity amongst family members was reported by $24.8 \%$ of participants in Ambae, $48.0 \%$ in Aneityum and $39.6 \%$ in Efate.

and $39.6 \%$ in Efate.
Fresh fish intake ranged from approximately $10 \%$ in Ambae to $50 \%$ in Aneityum. Meat $10 \%$ in Ambae to $50 \%$ in Aneityum. M
and/or fish intake was highest in Efate, followed by Aneityum then Ambae $(P<0.001)$. Tinned meat was consumed only monthly or yearly by the majority of participants in Ambae and Aneityum, compared to consumption daily or weekly for $80 \%$ of participants in daily or $w$

Children in Efate reported taking more processed foods to school compared to children from Aneityum and Ambae who reported taking more local foods to school.

For males and females means of anthropometric measures were lowest in Ambae (rural), intermediate in Aneityum (rural with tourism) and highest in Efate (suburban). Risk factors for obesity included consuming canned fish (OR 2.91 
Table 4 Characteristics and main findings of studies assessing fish consumption ${ }^{\mathrm{a}}$ (Continued)

Polynesia

French Polynesia

Clero et al. [36]

229 cases :203 women and 26 men diagnosed with thyroid controls: matched to cases by sex and age cancer from 1979 to 2004371

Intake of fish and type of fish consumed Median urinary iodine excretion (UIE), iodine sufficiency and association between fish consumption iodine sufficiencyAssociatio between thyroid volume and UIE

\section{Case-control study:} 66-item FFQ

nergy intake (kcal), iodine nutrition status and risk of thyroid cancer

\section{Case-control study:} 66-item FFQ and 26 men diagnosed with thyroid cancer from 1979 to 2004371 controls: matched to cases by

sex and age

Dewailly et al.[38]

214 pregnant women

who gave birth between

October 2005 and February

2006 and their neonates

Association between dietary pattern and thyroid cancer ris

Cross sectional study: Face-to-face survey Blood sample taken from the umbilical
Cross sectional study:

Face-to-face dietary

surveySpot urine sample

Thyroid volume
$95 \% \mathrm{Cl} ; P=0.020)$ and consuming multiple fish/meat dishes (OR 3.24, $95 \% \mathrm{Cl} ; P=0.010)$

$39 \%$ of children reported eating fish

on at least a weekly basis and $44 \%$ on a monthly basis. Canned fish consumption was reported by $70 \%$ of participants.

Eating fish at least monthly was associated

with urinary iodine sufficiency (UIE $>100 \mathrm{ug} / \mathrm{L}$ $P=0.011 ; P=0.045$ after adjusting for location, age and sex).Children were moderately iodine deficient and had much larger thyroid

glands compared to international reference values.

A statistical significant inverse correlation between thyroid volume and UIE for boys $(r=-0.444, P=0.001 ; n$ 77) and girls $(r=-0.319$ $P=0.005 ; \mathrm{n} 76)$

Cases consumed a mean $71 \mathrm{~g} /$ day of fish and shellfish compared to $83 \mathrm{~g} /$ day in controls.lodine nutrition deficiency ( $<150 \mathrm{ug} /$ day) was observed

in $60 \%$ of cases and controls. $30 \%$ had optimal iodine nutrition (150-299 ug/day).Risk of thyroid cancer decreased significantly with increasing

consumption of fish $(P=0.008)$ and shellfish

$(P=0.002)$. Subjects with a severe or moderate iodine nutrition deficiency had a 2.6 times

increased risk of thyroid cancer $(95 \% \mathrm{Cl}: 1.12$,

5.93) compared to subjects with optimal iodine nutrition status.

2 major dietary patterns were identified Western and traditional Polynesian. The traditional Polynesian pattern was inversely associated with risk of thyroid cancer. After adjustment for total energy intake, a $42 \%$ reduced risk of thyroid cancer was found for the highest vs. the lowest tertile: (OR $-0.58 ; 95 \%$ Cl: $0.35,0.95 ; P=0.02$ ) The decreased risk was attenuated after multivariate adjustment $(p=0.2)$ cord of neonates
Monthly fish intake type of fishlodine (I), polyunsaturated fatty acid (n-3 PUFA) concentrations selenium (Se) and omega 3

consumption was 33 meals/month
In pregnant women, mean fish of which 21.3 and 11.5 meals/ months were from reef and pelagic fish respectively. Tuna (75\%) was the most common pelagic fish

species consumed Mean umbilical iodine cord blood concentrations 
Konishi et al. $\quad 19$ females (aged $40-59$ years) and their spouses (15) from Kolovai village
Cross sectional study:

Face-to-face 24 h dietary

conseculive days during

Anthropometric assessment

of weight and height

Mixed methods

Households and

individuals: structured

questionnaires.

Key informant interviews

Fishermen: Semi-structured

interviews
Protein intake (g) and contribution of local fish and imported meats to

nutrient intakeWeight $(\mathrm{kg})$

height $(\mathrm{cm})$ and $\mathrm{BMl}\left(\mathrm{kg} / \mathrm{m}^{2}\right)$

varied between different archipelagos. Highest mean concentration of iodine was $2.60 \mathrm{umol} / \mathrm{L}$ and the lowest was $0.46 \mathrm{umol} / \mathrm{L}$. Mean cord blood selenium concentration was 2.0 umol/L. Mean concentration of n-3 PUFAs in red cell membrane phospholipids was $3.52 \%$.

Eicosapentanoic acid (EPA) and

docosahexanoic acid (DHA)

represented $87 \%$ of all n-3 PUFAs

Daily protein intake was $112 \mathrm{~g}$ and $97 \mathrm{~g}$ for men and women respectively.

$97 \%$ of participants were considered

to have adequate protein intake Fish

contributed $20 \%$ toward total protein intake compared to the sum of the two major imported meats mutton and chicken ( $23 \%$ of total protein intake). Mutton $(23 \%)$ and chicken (10\%) were the highest sources of fat in the diet.Mean BMl was $32.3 \mathrm{~kg} / \mathrm{m}^{2} \pm 4.4 \mathrm{~kg} / \mathrm{m}^{2}$ and $36.3 \mathrm{~kg} / \mathrm{m}^{2} \pm 5.4 \mathrm{~kg} / \mathrm{m}^{2}$ for men and women respectively (>15 years), households, key informants, 41 loca fisherman

Smith et al. [49]

443 school students aged 11-16 years from

Tongatapu, Vava'u

and Hapa'ai.

Cross sectional study:

Self-administered health

behaviour survey

Anthropometric

assessment including

height (cms)

weight (kgs)

Samoa and American Samoa

Craig et al. [47] 594 fishermen and 20 males aged 43-72 years from Ofu,

Cross sectionalObservation

of fishing activities and

semi-structured interviews
Fishing practices

Fisheries, agricultural production

and handicrafts all contributed

to income generation. Fisheries

ranked higher than agriculture

rank hagher than ariculure

three main objectives: to secure

subsistence, fulfil social obligations

and contribute to the cash

economy.

Fish $^{\mathrm{a}}$ was consumed by entire community.

$93 \%$ of village also consume other seafood

and $78 \%$ consume canned fish.

Intake of canned fish

mutton and beef

Prevalence of

overweight and obesity

$35 \%$ of participants reported consuming canned fish once or more a day compared to $57 \%$ who reported consuming canned mutton or beef once or more a dayThe prevalence of overweight and obesity was $36 \%$ amongst

boys and $54 \%$ amongst girls using international cut-off points for BMI.

Annual fish consumption

Per capita fish catch was $71 \mathrm{~kg} .63 \mathrm{~kg}$ of catch was consumed per capita per annum. Remaining catch was either sold locally (60\% of fishers 
Table 4 Characteristics and main findings of studies assessing fish consumption ${ }^{\text {a }}$ (Continued)

\begin{tabular}{lll}
\hline & Olosega and Sili villages in & with fishermenFree-form \\
& American Samoa & interviews of 20 males \\
DiBello et al. [58] & 723 American Samoans & Cross sectional study: \\
& and 785 Samoans aged & Anthropometric assessment \\
& (weight (kg), height (cm) and \\
& waist circumference). Fasting \\
& blood samples and blood \\
& pressure were measured.FFQ ( \\
& 42 -item American Samoa \\
& and 55-item Samoa)
\end{tabular}

and 55-item Samoa)

Cross sectional study:

27-item, 7-day FFQ

Knowledge, attitudes

and practices questionnaire

$15-64$ years located

in Ponhpei

Federated States of Micronesia

Corsi et al. [37] 293 females aged

Englberger et al.

[55]

Kosrae267 children aged 24-59 months and their caretakers 65 children aged 24-59 months and their caretakers
Cross sectional study:

34-item 7-day FFQ

Three non-consecutive

$24 \mathrm{~h}$ dietary recall

questionnaires
Prevalence of metabolic

syndromeAssociation

between dietary pattern

and metabolic syndrome

sold catch at least occasionally) or sent

to family members on Tutuila Island.

The prevalence of metabolic syndrome

was $49.4 \%$ and $30.6 \%$ in American Samoan

and Samoan samples respectively'Neo

traditional' and 'modern' dietary patterns

derived.

The 'neo-traditional' pattern was characterised

by high intake of crab and lobster, fish,

coconut cream dishes, papaya soup, coconut

milk, papaya.

Significant increasing prevalence

of metabolic syndrome across increasing

quintiles of the 'modern' dietary pattern

in Samoa $(P=0.05)$.

The 'neo-traditional' dietary pattern was

associated with an increase in $\mathrm{HDL}$ cholesterol

in America Samoa $(P=0.02)$ and decreased

waist circumference in both communities

$(P=0.03)$

Fish and meat

consumption

Cash expenditure

on food; factors

affecting food intake

ntake of total Vitamin A

retinol and protein $(\mathrm{g})$

Sources of vitamin A

$79 \%$ of participants reported frequent consumption of local fish/seafood.

Local fish/seafood was consumed twice

as frequently (4.8 days/week) compared to

imported fish/seafood (2.4 days/week).

Imported meats such as turkey tail were

consumed more frequently 1.9 days/week)

than local meats (1.3 days/week). $8 \%$ of

participants reported their household relied

on farming and fishing for their primary

income $6 \%$ relied on fishing alone.

Household food expenditure for $77 \%$ of

participants was half or more of their monthly income

$52 \%$ of participants purchased local food

for half or more than

half of a month.Consuming imported food

was regarded as a sign of wealth and status

by participants

Main dietary components included imported products

of rice, flour, chicken, other meats

and tinned fish and local products

of breadfruit, banana, taro, fish and other

seafood.

The most frequently consumed protein

food was imported frozen chicken

followed by local fish. 
Pobocik et al.

ross sectional study: Multiple-pass telephone

$24 \mathrm{~h}$ dietary recall

Self reported weight

$(\mathrm{kg})$ and height $(\mathrm{m})$
Fish and other meat intake $\mathrm{BMI}\left(\mathrm{kg} / \mathrm{m}^{2}\right)$

mutton intake

Mean intake of protein $(54 \mathrm{~g}+10 \mathrm{~g})$

well above the estimated requirements.

Mean daily intake of total vitamin A for all children was less than half of the requirements estimated by WHO and the $F A O^{\#}$.

Animal sources provided $52-53 \%$ of vitamin A intake for both children and caretakers.

Most commonly reported meats consumed were chicken (reported 159 times), beef (148), fish (141), eggs (75), sausage/bacon/hot dogs (65), pork/ham (60) and canned meat (42).Canned and processed meats accounted for $21 \%$ of all reported meat intake.

When fish was consumed $47 \%$ was fresh and the remaining was canned or dried. Mean BMI was $25.7 \mathrm{~kg} / \mathrm{m}^{2} \pm 5.8 \mathrm{~kg} / \mathrm{m}^{2}$ with significant differences in BMl by ethnicity $(P<0.05)$

\section{Multiple PICTs}

Phongsavan et al. [40] 4885 school children aged Cross sectional study: $\begin{array}{ll}13-15 \text { years from Republic of Vanuatu, } & \text { Self-administered Health } \\ \text { Behaviour and Lifestyle }\end{array}$ and Federated States of Pacific Youth (HBLPY) of Micronesia survey.

In Vanuatu, canned fish was consumed on a daily basis by $40 \%$ of students and canned mutton $17 \%$ of students.

In Tonga $32 \%$ of students consumed canned fish on a daily basis and $52 \%$ of students consumed canned mutton daily. In Pohnpei students were asked about consumption of fresh fish - $42 \%$ reporting consuming fresh fish on a daily basis and $46 \%$ consumed canned mutton daily 
Table 5 Characteristics and main findings of studies assessing the contribution of fishing to Pacific Islander livelihoods

Middlebrook \&

Williamson [61]

cunivanua and

Namatakula, Island

of Viti Levu40 heads

of households

Study Design ${ }^{\text {a }}$

Cross sectional

30 senior heads of

households in 198259

households in 2002

Cross sectionalSelf

administered household

questionnaires

Cross sectional

household and

individual

questionnaires

heads of households

86 adult individuals

(aged $>21$ years)

Lau Province,

25 experienced

local fishers

53 senior heads

of households
Outcome measures ${ }^{a}$

Key findings ${ }^{a}$

Mean weekly household income and fish yield per capital.Daily fish intake per capita (g) and

contribution of marine

sources to protein intake.

Household income,

source of income and

household fishing activity

characteristics of

household, household

livelihood activities and

household fishing activities

Time spent fishing importance of fishing
Total annual landings of finfish decreased by $27 \%$ from 1982 to 2002 No significant change in yield of finfish per capita of population $(96.9 \mathrm{~kg}$ per capita/year in 1982 to $93.7 \mathrm{~kg}$ capita/year in 2002)

Seafood remained the main source of protein between 1982 and 2002. Consumption of canned fish increased from $9 \mathrm{~g} / \mathrm{man} /$ day to

$19 \mathrm{~g} / \mathrm{man} /$ day

Ucunivanua: Mean monthly household income of FJS

$411.75 \pm 73.51$ (SD)

Income generated through fishing activities (75\%), with $20 \%$ from farming and $5 \%$ from wage-paid jobs.

Namatakula: Mean monthly household income of FJ\$ $432.25 \pm 54.65$ (SD) a month Income generated through wage-paid work ( $80 \%$, with $10 \%$ from fishing and $10 \%$ from personal business.

Mean annual household income was FJ\$2921.88.1 \% of households engaged in fishing, $76.3 \%$ in growing crops and/or gleaning.

The livelihood that generated the most cash and food overall was salaried work in Suva $32 \%$ households) followed by fishing (27\%) and gleaning (20\%).

No significant change in overal time spent fishing in the past 6-10 years. Income-generating activities had increased in importance over previous 10 years relative to fishing activities Consumption of fresh fish was significantly lower compared to estimates of past consumption $(Z=-3.774, p<0.001)$.Greatest decline in fish consumption was for income generation,

patterns of fish

consumption and

awareness of ecological

change within the local

qoliqoli (fishing ground)

face-to-face$$
\text { coliqoli (fishing ground) }
$$ 
Table 5 Characteristics and main findings of studies assessing the contribution of fishing to Pacific Islander livelihoods (Continued)

associated with highest mean

household income

80-100\% of households

that engaged in fishing

only $7 \%$ of households

ranked fishing as the primary

household occupation.

Solomon Islands

Albert et al. [64]

Papua New Guinea

Cinner et al. [63]

Ahus Island

51 households

representatives

Face-to-face

interviews

Cross sectional

interviews with

open-ended,

semi-structured and

structured questions

Fishing activities

including subsistence

and commercial activities
Annual fish catch and contribution of FAD

to fish catchBenefits

and negative aspects

household and

community level

Percent of households

engaged in fishing and

mportance of fishing

relative to other livelihood

activities

Near shore FADs contributed

$31-45 \%$ of the total annual

catch (mean $7500 \mathrm{kgs})$.Perceived

benefits from the FADs included:

provided a source of family income,

improved nutrition, more fish

available for community events.

The negative aspect of FADs was

a reduced contribution of fishers

to household activities due to

increased time spent fishing

$>96 \%$ of households were

engaged in fishing and >76\%

ranked fishing as their primary

occupation. Due to the remoteness

of the Island participants reported

few opportunities to engage

in other economic sectors.

$60 \%$ of participants fished on

average 2 days per week; $10 \%$

did not fish at all.56 \% of participants

reported dependence on lagoon

fishing for at least half of their food and/or cash income. $19 \%$ of

participants considered

themselves commercial fishers and

$41 \%$ subsistence fishers

Kingdom of Tonga

Kronen \& Bender [43]

Lofanga Island

Individual adults

(>15 years), households,

key informants, 41 local

fisherman

a) Fishing practices

including contribution

of fish to livelihood

$\begin{array}{ll}\text { individuals: structured } & \text { of fish to livelihood } \\ \text { questionnaires Key informant } & \text { and weekly fish }\end{array}$

$\begin{array}{ll}\text { questionnaires.Key informant } & \text { and weekly fish } \\ \text { interviewsFishermen: } & \text { consumption through }\end{array}$

Semi-structured interviews

Fisheries, agricultural production and handicrafts all contributed to income generation. Fisheries ranked higher

than agriculture and handicrafts.

Fisheries filled three main objectives:

to secure subsistence, fulfil social

obligations and contribute to 
Table 5 Characteristics and main findings of studies assessing the contribution of fishing to Pacific Islander livelihoods (Continued)

consumed by entire community.

$93 \%$ of village also consume other seafood

and $78 \%$ consume canned fish.

Micronesia

Federated States of Micronesia

Corsi et al. [37]

293 females aged

15-64 years locate

in Ponhpei
Cross sectional study:27-item,

7-day FFQKnowledge, attitudes

and practices questionnaire
Fish and meat consumption

Cash expenditure on food;

factors affecting food intake
$79 \%$ of participants reported

frequent consumption of local

fish/seafood. Local fish/seafood

was consumed twice as frequently

(4.8 days/week) compared to

imported fish/seafood (2.4 days/week)

Imported meats such as turkey tail

were consumed more frequently 1.9

days/week) than local meats (1.3 days/week).

$8 \%$ of participants reported their household

relied on farming and fishing for their

primary income $6 \%$ relied on fishing alone.

Household food expenditure for $77 \%$

of participants was half or more of their monthly

income $52 \%$ of participants purchased
local food for half or more than half of a month.

Consuming imported food was regarded

as a sign of wealth and status

by participants

${ }^{a}$ Note: When describing the design, outcome measures and findings of each study only details relevant to this systematic literature review were included in the summary table ${ }^{\mathrm{b}}$ Fish: Refers to fresh fish unless otherwise specified 
Table 6 Vanuatu case study: demographic, nutrition and fish data

\begin{tabular}{|c|c|c|c|c|c|c|}
\hline \multicolumn{5}{|l|}{ Indicator } & Result & Ref \\
\hline \multirow[t]{2}{*}{ Population } & \multicolumn{4}{|l|}{ All } & 276,579 & [94] \\
\hline & \multicolumn{4}{|c|}{$<5$ years } & 35000 & [95] \\
\hline \multirow[t]{2}{*}{ Life expectancy at birth } & \multicolumn{4}{|l|}{ Male } & 70 years & [96] \\
\hline & \multicolumn{4}{|c|}{ Female } & 73 years & \\
\hline \multicolumn{5}{|l|}{ Births per year } & 7911 & [2] \\
\hline \multirow[t]{2}{*}{ Mortality/1000 } & \multicolumn{4}{|l|}{ Infant } & 28 & [96] \\
\hline & \multicolumn{4}{|c|}{ Under 5} & 31 & \\
\hline \multicolumn{5}{|l|}{ Household expenditure on food } & $49.8 \%$ & [97] \\
\hline \multicolumn{7}{|l|}{ Nutrition } \\
\hline \multicolumn{5}{|l|}{ Vitamin A deficiency in pre-school aged children } & $16 \%$ & [98] \\
\hline \multirow[t]{3}{*}{ Nutritional status among children $<5$ years: } & \multicolumn{4}{|c|}{ Stunting } & $28.5 \%$ & [96] \\
\hline & \multicolumn{4}{|c|}{ Wasting } & $4.4 \%$ & \\
\hline & \multicolumn{4}{|c|}{ Underweight } & $10.7 \%$ & \\
\hline Nutritional status among adults & \multicolumn{2}{|c|}{ overweight or obese: } & \multicolumn{2}{|l|}{ Women } & $49.5 \%$ & [96] \\
\hline \multirow[t]{4}{*}{ aged $15-49$ years } & & & \multicolumn{2}{|l|}{ Men } & $35.8 \%$ & \\
\hline & \multicolumn{4}{|c|}{ Raised blood pressure: } & $47.2 \%$ & [99] \\
\hline & \multicolumn{4}{|c|}{ Raised blood glucose: } & $19 \%$ & {$[100]$} \\
\hline & Raised & lesterol: & & & $37.6 \%$ & [101] \\
\hline Energy (kcal) available per capita & & & & & 2820 & [102] \\
\hline Diet composition of population: & Carbo & & & & $60 \%$ & [103] \\
\hline & Fat & & & & $31 \%$ & \\
\hline & Total & & & & $9 \%$ & \\
\hline Infant feeding practices: & Childr & $s$ are ever br & & & $94.9 \%$ & [96] \\
\hline & Infants & breastfeed & lonths & & $72.6 \%$ & \\
\hline Households consuming adequate iodised sa & & & & & $50.7 \%$ & [96] \\
\hline Fish and fisheries & Nation & & Rural & Coastal & & {$[27,97]$} \\
\hline Annual per capita fish consumption (kg) & 20.3 & 19.3 & 20.6 & 29.9 & & \\
\hline Subsistence fishing & $51 \%$ & $17 \%$ & $60 \%$ & - & & \\
\hline Purchased & $49 \%$ & $83 \%$ & $40 \%$ & - & & \\
\hline Consumption of fresh fish & $60 \%$ & $38 \%$ & $65 \%$ & $72 \%$ & & \\
\hline Fish as $\%$ of total protein consumption & Total & & & & $14.9 \%$ & [102] \\
\hline & Anima & & & & $35.8 \%$ & \\
\hline Forecasts of fish required for food (tonnes) & 2010 & & & & 8200 & {$[27]$} \\
\hline & 2020 & & & & 10700 & \\
\hline & 2030 & & & & 13600 & \\
\hline Rural households engaged in fishing activiti & & & & & $72 \%$ & [104] \\
\hline Dependence on fisheries for income: & Marine & tivities & & Urban & $11 \%$ & {$[105]$} \\
\hline & & & & Rural & $39 \%$ & \\
\hline & Fresh & g activities & & Urban & $4 \%$ & \\
\hline & & & & Rural & $21 \%$ & \\
\hline Official fishing contribution to GDP & & & & & $0.8 \%$ & [104] \\
\hline Contribution of fish access fees to national & & & & & $1.2 \%$ & [104] \\
\hline
\end{tabular}


Table 7 Kiribati case study: demographic, nutrition and fish indicators

\begin{tabular}{|c|c|c|c|c|c|c|}
\hline \multicolumn{5}{|l|}{ Indicator } & Result & Ref \\
\hline \multirow[t]{2}{*}{ Population } & \multicolumn{4}{|l|}{ All } & 101,000 & [95] \\
\hline & \multicolumn{4}{|l|}{$<5$ years } & 11000 & [95] \\
\hline \multirow[t]{2}{*}{ Life expectancy at birth } & \multicolumn{4}{|l|}{ Male } & 65 years & [106] \\
\hline & \multicolumn{4}{|l|}{ Female } & 70 years & \\
\hline \multicolumn{5}{|l|}{ Births per year } & 2000 & [107] \\
\hline \multirow[t]{2}{*}{ Mortality/1000 } & \multicolumn{4}{|l|}{ Infant } & 25.6 & [108] \\
\hline & \multicolumn{4}{|l|}{ Under 5} & 60 & \\
\hline \multicolumn{5}{|l|}{ Household expenditure on food } & $46 \%$ & [109] \\
\hline \multicolumn{7}{|l|}{ Nutrition } \\
\hline \multicolumn{5}{|l|}{ Vitamin A deficiency in pre-school aged children } & $22 \%$ & [98] \\
\hline \multirow[t]{3}{*}{ Nutritional status among children $<5$ years: } & \multicolumn{4}{|l|}{ Stunting } & - & \\
\hline & \multicolumn{4}{|l|}{ Wasting } & - & \\
\hline & \multicolumn{4}{|c|}{ Underweight } & $14.9 \%$ & [108] \\
\hline Nutritional status among adults & \multicolumn{2}{|c|}{ overweight or obese: } & \multicolumn{2}{|l|}{ Women } & $78.9 \%$ & [110] \\
\hline \multirow[t]{4}{*}{ aged $15-49$ years } & & & \multicolumn{2}{|l|}{ Men } & $67.4 \%$ & \\
\hline & \multicolumn{4}{|c|}{ Raised blood pressure: } & $37.4 \%$ & [99] \\
\hline & \multicolumn{4}{|c|}{ Raised blood glucose: } & $21.4 \%$ & [100] \\
\hline & Raised blo & sterol: & & & $35.5 \%$ & [101] \\
\hline Energy (kcal) available per capita & & & & & 3022 & [111] \\
\hline Diet composition of population: & Carbohyd & & & & $58.6 \%$ & [103] \\
\hline & Fat & & & & $31 \%$ & \\
\hline & Total prot & & & & $10.5 \%$ & \\
\hline Infant feeding practices: & Children $<$ & are ever brea & & & $83 \%$ & [108] \\
\hline & Infants ex & oreastfeed tc & inths & & $69 \%$ & \\
\hline Households consuming adequate iodised sa & & & & & $5 \%$ & [112] \\
\hline Fish and fisheries & National & Urban & Rural & Coastal & & [27] \\
\hline Annual per capita fish consumption (kg) & 62.2 & 67.3 & 58 & 115.3 & & \\
\hline Subsistence fishing & $63 \%$ & $46 \%$ & $79 \%$ & - & & \\
\hline Purchased & $37 \%$ & $54 \%$ & $21 \%$ & - & & \\
\hline Consumption of fresh fish & $92 \%$ & $91 \%$ & $93 \%$ & $95 \%$ & & \\
\hline Fish as $\%$ of total protein consumption & Total prot & & & & $28.8 \%$ & [29] \\
\hline & Animal pr & & & & $55.9 \%$ & \\
\hline Forecasts of fish required for food (tonnes) & 2010 & & & & 7730 & [27] \\
\hline & 2020 & & & & 9050 & \\
\hline & 2030 & & & & 10230 & \\
\hline Rural households engaged in fishing activiti & & & & & $60 \%$ & [113] \\
\hline Dependence on fisheries for income : & Sales of fis & gricultural & & Urban & $26 \%$ & [113] \\
\hline & crops for & me: & & Rural & $34 \%$ & \\
\hline & Paid work & 'agriculture & & & $19.5 \%$ & [113] \\
\hline & And fisher & & & & & \\
\hline Official fishing contribution to GDP & & & & & $0.8 \%$ & [104] \\
\hline Contribution of fish access fees to national $r$ & & & & & $42 \%$ & [104] \\
\hline
\end{tabular}


Table 8 Tonga case study: demographic, nutrition and fish indicators

\begin{tabular}{|c|c|c|c|c|c|c|}
\hline \multicolumn{5}{|l|}{ Indicator } & Result & Ref \\
\hline \multirow[t]{2}{*}{ Population } & \multicolumn{4}{|l|}{ All } & 103,252 & [114] \\
\hline & \multicolumn{4}{|l|}{$<5$ years } & 14,000 & [95] \\
\hline \multirow[t]{2}{*}{ Life expectancy at birth } & \multicolumn{4}{|l|}{ Male } & 65 years & [115] \\
\hline & \multicolumn{4}{|l|}{ Female } & 69 years & \\
\hline \multicolumn{5}{|l|}{ Births per year } & 2,896 & [114] \\
\hline \multirow[t]{2}{*}{ Mortality/1000 } & \multicolumn{4}{|l|}{ Infant } & 7 & [116] \\
\hline & \multicolumn{4}{|l|}{ Under 5} & 18 & [116] \\
\hline \multicolumn{5}{|l|}{ Household expenditure on food } & $50.6 \%$ & {$[117]$} \\
\hline \multicolumn{7}{|l|}{ Nutrition } \\
\hline \multicolumn{5}{|l|}{ Vitamin A deficiency in pre-school aged children } & $17 \%$ & [98] \\
\hline \multirow[t]{3}{*}{ Nutritional status among children $<5$ years: } & \multicolumn{4}{|l|}{ Stunting } & $8.1 \%$ & [116] \\
\hline & \multicolumn{4}{|l|}{ Wasting } & $5.2 \%$ & \\
\hline & \multicolumn{4}{|c|}{ Underweight } & $1.8 \%$ & \\
\hline \multirow{5}{*}{$\begin{array}{l}\text { Nutritional status among adults } \\
\text { aged } 15-49 \text { years }\end{array}$} & \multicolumn{2}{|c|}{ overweight or obese: } & \multicolumn{2}{|l|}{ Women } & $79.6 \%$ & [110] \\
\hline & & & \multicolumn{2}{|l|}{ Men } & $69.9 \%$ & \\
\hline & \multicolumn{4}{|c|}{ Raised blood pressure: } & $41 \%$ & [99] \\
\hline & \multicolumn{4}{|c|}{ Raised blood glucose: } & $18 \%$ & {$[100]$} \\
\hline & \multicolumn{4}{|c|}{ Raised blood cholesterol: } & $50 \%$ & [101] \\
\hline \multicolumn{5}{|l|}{ Energy (kcal) available per capita } & - & \\
\hline Diet composition of population: & Carbohyc & & & & - & \\
\hline & Fat & & & & - & \\
\hline & Total pro & & & & - & \\
\hline Infant feeding practices: & Children & are ever & & & $91 \%$ & [116] \\
\hline & Infants e) & breastfe & honths & & $52.2 \%$ & \\
\hline Households consuming adequate iodised sal & & & & & - & \\
\hline Fish and fisheries & National & Urban & Rural & Coastal & & {$[27,117]$} \\
\hline Annual per capita fish consumption (kg) & 20.3 & - & - & 84.6 & & \\
\hline Subsistence fishing & $37 \%$ & - & - & - & & \\
\hline Purchased & $63 \%$ & - & - & - & & \\
\hline Consumption of fresh fish & $80 \%$ & - & - & $87 \%$ & & \\
\hline Fish as $\%$ of total protein consumption & Total pro & & & & $13.5 \%$ & [118] \\
\hline & Animal $p$ & & & & $23.4 \%$ & \\
\hline Forecasts of fish required for food (tonnes) & 2010 & & & & 3,490 & [27] \\
\hline & 2020 & & & & 3,690 & \\
\hline & 2030 & & & & 3,900 & \\
\hline Households engaged in fishing activities & & & & & $33 \%$ & [119] \\
\hline Dependence on fisheries for income : & Workforc & ed in fisł & istry & & $3 \%$ & [120] \\
\hline Official fishing contribution to GDP & & & & & $4.1 \%$ & [104] \\
\hline Contribution of fish access fees to national re & & & & & $0.2 \%$ & [104] \\
\hline
\end{tabular}

1.5 days per week. Reasons identified for declining fish consumption were a dependence on other family members to catch fish, or a need to purchase rather than catch their own fish (possibly due to more time spent on income-generating activities [42]), as well as increased consumption of other purchased foods. 


\section{French Polynesia}

Two separate studies assessed fish intake in French Polynesia. In a cross sectional study of pregnant women participants, there was a mean consumption of 33 meals/month of reef and pelagic fish, however, data on actual grams per day were not collected [38]. In a casecontrol study of thyroid cancer patients, an average of $71 \mathrm{~g} /$ day and $83 \mathrm{~g} /$ day of fresh fish and/or shellfish was consumed by cases and controls, respectively [36].

\section{Guam}

In contrast to other Pacific Islands, Pobocik et al. [51] reported that in adults from Guam, fish contributed only $3.5 \%$ of foods eaten but was the third most commonly consumed meat, after chicken and beef. Of the fish that was consumed, only $47 \%$ was fresh and the remaining canned or dried [51].

\section{New Caledonia}

Three studies assessed fish intake in New Caledonia. In the Northern Province, $85 \%$ of adults participating in a study of subsistence fishing practices reported consuming fresh fish one or more times a week, with $45 \%$ consuming fresh fish 2-3 times/week and 11 \% 1-2 times/day [50]. Of annual fish consumption, $92 \%$ was classified as subsistence and $8 \%$ was purchased [50]. Subsistence production was also the main fish supply for two-thirds of households on Ouvéa Island, New Caledonia, with annual intake of fish considerably higher than reported in the Northern Province [48]. In a small study of 146 local fishers from the northwest coast, approximately $18 \mathrm{~kg}$ of fish per capita per annum was consumed, however, only reef fish intake was considered, not pelagic species nor imported fish [44].

\section{Solomon Islands}

In Tikopia, an isolated island in Solomon Islands, Mertz et al. [41] reported that $72 \%$ of households consumed fresh fish daily, whereas canned fish was eaten only when rarely available [41].

\section{Tonga}

On Lofanga Island, Tonga, the entire community reported eating fresh fish, with $93 \%$ also consuming other seafood and $78 \%$ of the community consuming canned fish. However, a decline in fresh fish consumption was attributed to increased income resources [43]. In a cluster random sample of schools in Tonga, approximately a third (27.2 to $38.6 \%)$ of 13- and 15-year-old girls and boys who completed the HBLPY study reported consuming canned fish on a daily basis and half the students consumed canned mutton daily [40]. However, it is not known how many students consumed fresh fish as those data were not collected.

\section{Vanuatu}

In Vanuatu, fish consumption varied between islands but, overall, fresh fish consumption was lower than for Solomon Islands and Tonga. The percentage of adults consuming fresh fish during the previous $24 \mathrm{~h}$ ranged from 10 to $50 \%$, depending on the island. No data were available on the amount of fish consumed [46]. On Aneityum, considered to be a rural island with tourism, children were more likely to consume tinned fish than adults. These findings were similar to those of Phongsavan et al. [40] who reported that $40 \%$ of students in the HBLPY survey reported consuming canned fish on a daily basis. On the rural island of Tanna, $39 \%$ of primary school children consumed fish at least weekly, with the majority $(70 \%)$ consuming mainly canned fish. Fish consumption differed among the four study sites in Vanuatu, with more fish consumed in coastal villages than in urban centres [39].

\section{Contribution of fish consumption to energy and/or protein intake}

Fish/seafood was also identified as the primary source of dietary protein in five of the six small-scale studies that addressed contribution of fish consumption to protein intake [41, 45, 52-54]. Consumption differed across PICTs, ranging from $20 \%$ of total protein intake in the Kolovai village in Tonga [53] to $37.4 \%$ in Verata, Fiji [54].

\section{Federated States of Micronesia}

In Kosrae, a cross-sectional survey of children and their caretakers reported that local fish was the second most commonly consumed source of protein, after cooked chicken [55]. Mean intake of protein, both for children and adults, was above the average requirements, as defined by Latham [56].

\section{Fiji}

In one rural village in Fiji, the second and third sources of protein intake after fish and shellfish $(37 \%)$ were cereals $(29.2 \%)$ and meat (13\%). Higher marine food consumption was associated with lower cereal intake [54].

\section{Papua New Guinea}

Fish consumption in the Sepik-Ramu catchment area in Papua New Guinea differed between the four villages surveyed (two high altitude, one middle and one low) [57]. In the low altitude village, fish was the most important source of protein for residents and comprised $41 \%$ of all food from animal sources. Conversely, in high and middle altitude villages, animal protein comprised mostly purchased sources such as canned fish and lamb flaps [57]. 


\section{Solomon Islands}

In Solomon Islands, a cross sectional study of adults from five villages in Roviana Lagoon found that most households consumed fish as the primary source of protein but did not give details of alternative protein sources [52]. Mertz et al. [41] also reported fish as the primary source of protein among residents of Tikopia, a remote area in Solomon Islands. Just over half of households interviewed owned chickens, but meat from livestock was rarely eaten. Other sources of protein included canned fish and canned meat but these were rarely available.

\section{Tonga}

In Tonga, protein intake from fish was highest (20\%), followed by imported chicken (12\%) and mutton (11\%) [53].

\section{Fish consumption and nutritional outcomes}

Iodine status was reported in three studies [36, 38, 39]. In a case-control study of French Polynesians, inadequate iodine intake ( $<150 \mathrm{ug} /$ day) was observed in $60 \%$ of participants, with optimal iodine intake (150-299 ug/day) reported in only $30 \%$ of participants. Subjects with thyroid cancer were 2.5 times more likely to have intakes of $<75 \mu \mathrm{g} /$ day compared to control subjects [36]. The iodine concentration of umbilical cord blood of newborn babies also suggested that iodine intake was adequate in French Polynesian mothers [38]. Fish intake of the women was assessed during pregnancy, with mean fish consumption reported as 33 meals per month (21.3 meals per month from reef fish and 11.5 meals per month from pelagic fish); fish intake varied little between women from different archipelagos. This suggests that fish was consumed daily, however, data on actual grams consumed per day were not collected [38]. Mean blood concentration of iodine varied between newborn babies from different archipelagos, with the highest mean concentration in the Iles Sous Le Vent $(2.6 \mu \mathrm{mol} / \mathrm{L})$ and the lowest in the Australes $(0.46 \mu \mathrm{mol} / \mathrm{L})$ [38].

Li et al. [39] assessed the iodine status of children on the Island of Tanna, Vanuatu, by measuring the level of urinary iodine excretion (UIE), and reported moderate population-level iodine deficiency (median UIE $=49 \mu \mathrm{g}$ / l). Only $30 \%$ of participants reported consuming mostly fresh fish, with the remainder eating mainly canned fish.

In Kosrae, Micronesia, Englberger et al. [55] reported that the mean daily intake of total vitamin A for all infants was less than half of the requirements estimated by the WHO and the FAO [55]. Yet both protein and fat intakes were above the estimated requirements and results were similar for infants' caretakers. Highest intakes of total vitamin A and retinol were found in Malem, one of four Kosrae municipalities. Informants in the ethnographic analysis suggested that a wider range of seafood was consumed in Malem, including whole small fish consumed with the liver which is a rich source of vitamin A [55].

Assessing whole-of-diet against health outcomes was the approach used in five studies. A 'traditional' Polynesian dietary pattern, compared to a 'modern' dietary pattern, was shown to be associated with decreased risk of thyroid cancer in French Polynesia but the findings were no longer significant after accounting for several confounding variables including family history of thyroid cancer [33]. In Samoa, the 'modern' dietary pattern, characterised by high intakes of processed foods, was significantly associated with an increased prevalence of metabolic syndrome [58].

In Port Moresby, Papua New Guinea, two predominant dietary patterns were identified amongst a Naasioi migrant population [35]. Neither dietary pattern included high intakes of fresh fish but the 'traditional' dietary pattern was inversely associated with consumption of canned fish, rice and soft drinks [35]. Dietary patterns were not associated with body mass index (BMI) nor blood pressure [35]. A study of three villages in Vanuatu reported that both consumption of canned fish and multiple fish/meat dishes per day were risk factors for obesity, defined by both BMI and percentage body fat. Canned fish could lead to obesity because it is most commonly packaged with oil or sauce providing a higher fat content than fresh fish. Again, fresh fish intake was not considered in the analysis [59].

\section{Contribution of fishing activities to subsistence and/or cash income amongst Pacific Islanders}

The degree to which individuals and households depended upon fishing for livelihood varied between and within PICTs. Four of the studies reviewed were conducted in Fiji, one of the more economically developed countries in the region $[42,45,60,61]$.

\section{Federated States of Micronesia}

Fishing as the primary source of income or food has been described in many PICTs however, this is not the case for all PICTs. Pohnpei, in the Federated States of Micronesia (FSM), is considered to be one of the urban centres currently experiencing the nutrition transition. It was found that $65 \%$ of participants surveyed reported that one or more members of their household held a salaried position. Of the monthly household income, $77 \%$ participants reported that household food expenditure made up half or more of the budget. In contrast, farming and fishing was the primary source of income in $8 \%$ of participants and only $6 \%$ relied on fishing alone [37]. 
Fiji

In the Navakavu fishing grounds in the south eastern area of Fiji, 88 \% of households were involved in fishing activities. However, salaried work provided the most income and food for $32 \%$ of households, while $27 \%$ of households reported fishing as their most important resource [60]. On the island of Vitu Levu, two contrasting villages were studied; firstly, Ucunivanua, where fishing is the primary income activity for $75 \%$ of households. In Namatakula, the primary income source was provided from employment in local international hotels (fishing being primary income for only $10 \%$ of households) [61]. Despite primary sources of income differing between the two villages, there was no significant difference in total monthly income.

Key informants, local fisherman and senior heads of households, from four islands in the Lau Province of Fiji identified a decreasing dependency on fishing activities for livelihood over the past decade. Current fishing activities continued primarily for subsistence purposes, with the exception of fishing activities on Yaroi where fish was more commonly sold. Only $7 \%$ of households ranked fishing as the primary household occupation although almost all households remained engaged in fishing practices [42]. In the most southerly Fijian Island group of Ono-i-Lau, also part of the Lau province, the economy was again predominantly subsistence and this had not changed between the two study periods of 1982 and 2002 [45]. While it was reported that time spent fishing had not significantly changed in the past 10 years, engagement in other forms of livelihood activities had increased including formal employment and animal husbandry [42]. Fishing and gardens were the primary source of subsistence products but the key incomegenerating activities were sale of copra, seaweed farming and handicraft making. Income from these sources doubled between 1982 and 2002, but income remained insufficient at both time points to purchase sources of protein other than fish on a regular basis [45].

\section{French Polynesia}

In Moorea, French Polynesia, a subsistence economy of small-scale agriculture and fishing existed until about 1962 [62]. In a small sample of adults interviewed in 2002, over half reported dependence on lagoon fishing for at least half of their food and/or income [62]. However, there has been an influx of tourism, and agricultural production for export markets, which have largely replaced local food production, including fishing.

\section{Papua New Guinea}

On the island of Ahus, Cinner et al. [63] found that more than $76 \%$ of participants ranked fishing as their primary occupation. Participants reported that the remoteness of the island meant that there were few opportunities to engage in other economic sectors such as agriculture. Maintenance of marine tenure rights was important to create a demand for fish from the mainland [63].

\section{Solomon Islands}

The introduction of nearshore fishing aggregating devices (FADs) improved catch in four villages in Solomon Islands. These FADs contributed $31-45 \%$ to the total annual catch and $26-58 \%$ of the fish consumed annually $[62,64,65]$. The perceived benefits of FADs included provision of income through the sale of catch and improvements to diet through increased fish consumption [64].

\section{Tonga}

The Island of Lofanga is a traditional Tongan community in which the cash economy remains limited. On this island, fisheries, ranked higher than agriculture and handicrafts for importance to income generation, and were considered vital to secure subsistence and fulfil social obligations. However, in $45 \%$ of households studied, income was also received as financial remittances from relatives on other islands or overseas [43].

\section{Country case studies}

To highlight the heterogeneous nature of Pacific Islands, three PICTs, one from each of the cultural sub-regions, were examined in further detail. Demographic, nutritional and fish indicators from Vanuatu, Kiribati and Tonga (Tables 6, 7, and 8) demonstrate that fish consumption, as a percentage of total protein intake, varies considerably across the three cultural sub-regions. Fish consumption is much lower in Vanuatu, than in Kiribati and Tonga. This is presumably due to the relatively large population of Vanuatu and the limited area of coral reef capable of supporting coastal fisheries, resulting in low availability of fish per capita. The availability of beef cattle on some islands in Vanuatu, and the great importance of yams in the traditional diet, presumably also affect the role of fish in the nation's food system.

Nevertheless, the patterns of fish consumption evident from the case studies summarised in Tables 6, 7 and 8 are representative of differences among the three subregions in general, with average national fish consumption in Micronesia and Polynesia, being much greater than in Melanesia [27]. The case studies support the data presented in the numerous individual country studies identified in this review and are used to present a succinct summary overview of factors influencing fish consumption patterns, food security and health status between the sub-regions. 


\section{Discussion}

This review confirms that fish is an important staple food in most Pacific Island countries and territories, and that subsistence and commercial fishing activities make essential contributions to both household and individual food security, particularly in rural areas. Estimates of per capita annual fish consumption ranged from 18 to $63 \mathrm{~kg}$. The wide range of fish consumption can be attributed to variables such as geographical location (rural coastal villages versus urban centres), availability of alternative animal food sources (from both agriculture and imported foods) and whether the community has a subsistence or cashbased economy. These differences are highlighted in the three country case studies, showing higher fish consumption in Kiribati, one of the least developed PICTs.

Given the central contribution of fish to both dietary intakes and livelihoods in PICTs, it is noteworthy that our review identified only 29 relevant studies from 22 countries. Nationally representative data is sparse, and whole provinces and/or cultural groups are missing from the Melanesian countries. In a broader study, Bell et al. [27] used data from household income and expenditure surveys to quantify average national, rural and urban fish consumption per capita for 16 PICTs. Average national fish consumption ranged from $55 \mathrm{~kg}$ to $110 \mathrm{~kg}$ per person per year in eight PICTs, 3-6 times the average global consumption of $\sim 18 \mathrm{~kg}$ per person per year [66]. Importantly, fish provided 50-90\% of dietary animal protein in rural areas across a wide range of PICTs.

With ongoing population growth, coastal fisheries based on coral reef ecosystems are not expected to yield sufficient fish to maintain per capita fish consumption in several PICTs [27]. The rich tuna resources of the region will need to play a greater role in maintaining the food security of Pacific Island people [31]. However, as urbanisation increases and urban centres become more focused on cash economies, the risk is that greater availability of imported, energy-dense, nutrient-poor foods will exacerbate the dual burden of malnutrition that includes micronutrient deficiencies and infectious diseases, accompanied by non-communicable diseases. Food security involves not only access to sufficient food, but also to nutritious food. Therefore, easy and affordable access to fish will be essential in order to provide growing PICT populations with healthy sources of food.

It has been estimated that for optimal nutrition, Pacific Islanders need to consume approximately $34-37 \mathrm{~kg}$ of fish per annum (based on WHO recommendation of $0.7 \mathrm{~g}$ protein $/ \mathrm{kg}$ body weight/day and an assumption that fish will need to supply $50 \%$ of required protein) [27]. Dependence on fish for protein is particularly high in rural areas where there is limited access to other sources of protein, such as imported meats, and in areas where animal grazing and husbandry is not viable [27, 67]. Our review suggests that the majority of PICT communities for which data is presented consume sufficient protein to meet their nutritional requirements, however, a number of communities, particularly inland PNG, suffer from high rates of protein-energy malnutrition $[68,69]$. For these communities, an increase in the availability of fish has particular potential to contribute to improved nutritional outcomes. However, the remote nature of communities in PNG poses many challenges to increasing access to fish [27, 31]. To sustain recommended levels of fish consumption across the region as populations grow, new strategies are required to assist communities to obtain fish [27, 31]. A recent paper published after completion of this review reported that fishing remained the most important livelihood for households in the Langalanga region of the Solomon Islands but that households were involved in a range of different livelihoods in order to produce food and/or generate income. The authors suggested that households in this region had the ability to adapt to changing circumstances but that fisheries management involving local stakeholders was needed in order to ensure that fisheries continue to be a major source of food and income[70].

This review did not identify any reported interventions designed to test the hypothesis that increased availability of fish improves nutritional outcomes. Thus, our PICO question could not be answered directly. However, it is evident that fish is a highly nutritious food and that it provides a lean source of high biological value dietary protein as well as many essential fatty acids and micronutrients. In particular, the high iodine levels in fish and other seafood mean that improved access to increased fish availability may help prevent iodine deficiency, which remains highly prevalent in PICTs such as Fiji [71], PNG [72] and Vanuatu [39]. Improving iodine nutrition status through higher fish consumption may also contribute to the prevention of iodine-related diseases including goitre [39] and thyroid cancer [33, 36, 73]. In addition, the review suggests that some species of small fish that are eaten whole are important for the prevention of Vitamin A deficiency [30], which is highly prevalent in several PICTs including FSM [74], Kiribati [75], Marshall Islands [76], and PNG [72].

Sources of oily fish provide docosahexanoeic acid, and consumption of these fish by Pacific Islanders [38] may be making an important contribution to cognitive development in utero (through maternal fish intake), as well as in young children [30]. In other developing countries, such as Cambodia and Bangladesh, fish is an important source of calcium, iron and zinc [30], but data on the contribution of these nutrients from fish in PICTs are not available. Overall, further research is required to determine the extent of other micronutrient deficiencies that may exist in PICTs, such as iron or calcium and 
how fish consumption may contribute to reducing the risk of such deficiencies.

\section{Prevention and management of NCDs}

Non-communicable diseases have been declared a crisis in the Pacific, and there are national response plans in place to address risk factors, particularly with regard to strategies to reduce population-level salt intake. Dietary survey work in Fiji identified the main sources of salt in the diet as salt (and MSG) added during cooking and at the table, as well as processed foods such as tinned fish and meat, biscuits, soy sauce, noodles, salty crisps and snacks, tinned fruit and vegetables, butter and bread [77]. Country consultations and Food Frequency Questionnaires (FFQ) carried out in Fiji, Samoa, Kiribati and Cook Islands, have confirmed this [78]. Locally salted, preserved fish and meat, and meals eaten in and out of the home, such as Chinese dishes, soups and curries are also a common part of the diet in the region.

An increase in the availability of fresh fish offers an alternative to foods with a high salt content. Increasing access to fresh fish also offers an alternative to imported meats, many of which are energy-dense and high in saturated fat (e.g., frozen chicken, canned mutton, turkey tails and sausages). These energy-dense foods have been associated with the prevalence of chronic diseases and over-nutrition in PICTs, and their inclusion in emerging dietary patterns confirms this, as identified by studies identified in the current review.

'Modern' dietary patterns, characterised by high consumption of foods such as potato chips, cake, rice, instant noodles, soup, and low intakes of local foods, have been shown to be associated with an increased prevalence of metabolic syndrome [58]. In contrast, 'traditional' Pacific Island dietary patterns high in fresh fish and seafood, as well as other local foods, such as coconut-based dishes, taro and papaya, have been associated with reduced prevalence of metabolic syndrome, increased HDL cholesterol and reduced waist circumference [58]. Heavy reliance on poor-quality imported foods [79] is exacerbating the genetic predisposition of people in FSM to obesity [80].

Whether fish is consumed fresh or canned needs to be considered. Findings have been inconsistent as to whether consumption of canned fish per se is a risk factor for obesity in PICTs. Data collected between 2001 and 2002 from rural Tongan communities reported that neither fresh fish nor canned fish were related to obesity [81]. However, the more recent finding of Dancause et al. [59] that consumption of canned fish was a risk factor for obesity in Vanuatu warrants further consideration, in the context of the nutrition transition [5]. Methodological limitations to dietary assessment should be noted;
Dancause et al. used a single $24 \mathrm{~h}$ recall, which may not be appropriate to determine usual intake. Further, a higher consumption of tinned fish may simply be a proxy measure for a greater reliance on processed foods in place of fresh fish, as populations become more urbanized and adopt more westernised eating patterns. Both the nutrient content and the preparation methods of tinned fish may also contribute to its association with obesity. Tinned fish canned in oil or sauce has higher fat content than most types of fresh fish [82] and will often be served with instant noodles and rice [59]. Packaged instant noodles are popular in Vanuatu [83] and across most PICTs, and their inclusion in the diet has been shown to be associated with increased risk of obesity. In comparison, fresh fish and meat more often accompany dishes prepared with traditional root crops and vegetables, which are less energy-dense. A heavy reliance on tinned fish in urban areas was reported during the first nutrition survey conducted in Vanuatu as long ago as 1951 [84] and has since been observed in many other PICTs [83, 85, 86]. The Vanuatu Ministry of Health NCD survey in 1998 reported associations among obesity and daily consumption of non-traditional fat sources $(\mathrm{OR}=2.19)$, including oil, margarine/butter, milk, fresh meat, poultry, tinned meat, and tinned fish [87].

In short, it appears that any association of canned fish with obesity and NCDs may well be related to the foods eaten with canned fish, as well as the added oil or sauce used to preserve fish when canned [59]. On its own, canned fish is a valuable alternative source of protein, when fresh fish is in short supply due to unfavourable fishing conditions. While fresh fish remains a major part of the diet in Vanuatu, it is not available in all areas and only seasonally in others as shown in Table 6. It has been proposed, somewhat controversially, by Dancause et al. [59] that fresh meat might be a better dietary option than tinned fish in some PICTs, at least from the point of view of preventing NCDs. This requires further investigation with well designed intervention studies, but is considered impractical due to the limited scope for grazing cattle in most PICTs, as well as lack of refrigeration for storage. Animal husbandry (chickens and pigs) is already practiced widely but may have limited potential for further expansion due to the high costs of imported feeds.

The challenge is to encourage Pacific Islanders to maintain traditional dietary patterns in the face of urbanisation accompanied by the nutrition transition. To date, there have been surprisingly few publications on interventions in this regard. In FSM, a health promotion programme that encouraged the consumption of local foods, including banana, taro and breadfruit, demonstrated increased dietary diversity through higher consumption of local foods and a decrease in consumption of imported foods (such as rice) [91]. Such efforts could be used to promote the 
consumption of fresh fish in areas where intake of imported meats has become increasing prevalent.

\section{Food security}

Fishing is critical to household food security in PICTs through subsistence production and income generation (which allows food purchases) especially for communities that have limited opportunity to engage in other agricultural or economic sectors to produce food and/or income $[63,88]$. For example, although Fiji is one of the more developed PICTs, both subsistence and commercial fisheries remain an important source of food and livelihoods [60].

In 2010, at the Pacific Food Summit, a Framework for Action on Food Security in the Pacific was developed with four goals aligned to the WHO's four pillars for food security. The first goal, availability of food, has been addressed to some extent in the literature, with predictions that the majority of PICTs will have sufficient fish for local consumption and commercial activities, as long as Pacific Island governments provide greater access to regional tuna resources and the bycatch from industrial fishing operations for local consumption [31]. Even so, inter-annual variation in where bycatch is landed by fishing fleets could cause temporary shortfalls in fish supply in some urban centres [88].

Strategies such as increasing nearshore FADs have shown promise in terms of how increased availability of tuna and other large pelagic fish can help provide the protein that communities need for food security and nutrition [65], however appropriate monitoring and management is required. Strategies based on facilitating the supply of locally-canned tuna to the large inland population of PNG have yet to be developed in any detail but are much needed [27, 31].

The overview study by Bell et al. [27] showed that 50$90 \%$ of fish consumed in rural areas of PICTs was obtained through subsistence fishing. Other research done by the Coastal Fisheries Programme at the Secretariat of the Pacific Community [89] shows that an average of $\sim 50 \%$ of surveyed coastal households in 17 PICTs derived their first or second source of income from catching or selling fish.

However, there is limited research relating to two of the other goals, namely access to food and food utilisation. These goals are concerned with households' ability to grow or buy foods to meet dietary requirements for good health [90]. The fourth goal, relating to stability of food systems, is beyond the scope of this literature review.

When planning policies and interventions to increase availability of fish, ease of access to fish, and utilization of fish in PICTs, it is important to consider other factors that may affect food intake. A lack of nutrition education and a decrease in knowledge of traditional food sources in several PICTs also means that many Pacific Islanders do not have the knowledge or skills to make food choices that will benefit their health [55, 59, 91, 92]. This is increasingly problematic as more imported unhealthy foods become readily available. Qualitative evidence suggests imported, foods such as canned meats may be increasingly preferred by Pacific Islanders over local foods, such as fresh fish, because they are associated with wealth and status [37]. The ability to purchase imported foods is increasing for at least two reasons. First, more PICT communities are moving away from a subsistence to a cash-based economy. Second, increased migration to urban centres reduces opportunities for people to grow their own food, or have access to fish when it is difficult to transport them from remote areas to urban markets.

One of the limitations of this review is that the reported findings of detailed studies on consumption of fish are based on only a few of the PICTs, and primarily in coastal areas. Evidence from many PICTs has been limited to information derived from household income and expenditure surveys [27], with little data on the factors determining access to fish and use of fish at a local level. In addition, the majority of articles included in this review were cross-sectional, with only one longitudinal study and one case-control study. Comparison of fish consumption was also limited because measurement of fish consumption differed between studies in terms of daily frequency, meals per month and daily amount. No intervention studies were found assessing the effect of fish consumption on improved dietary intakes or health outcomes.

Finally, a lack of co-ordinated approaches between fisheries and health ministries has been acknowledged by the Secretariat of Pacific Communities (SPC) [93]. This has hindered the development of integrated policies designed to achieve food security through improved management and sustainability of coastal fisheries, while at the same time preventing NCDs. Such approaches are a priority for the region and will require inter-sectoral dialogue and partnership.

\section{Conclusions}

Recent literature confirms assumptions that fishing remains a major contribution to food security in Pacific Island countries and territories, through subsistence production and income generation (which allows food purchases). However, there is a paucity of research on how maintaining and/or improving fish consumption benefits the nutritional quality of the diets and health status of Pacific Islanders as they contend with the 
ongoing nutrition transition resulting from the influx of foods that are high in fat, sugar and salt. Given the significance of fish to food security and livelihoods, it is time for the region to develop a more integrated and coordinated approach to fisheries, health and food policy that identifies research priorities within national development challenges. A research and policy framework is required that addresses looming food security and public health crises caused by declining fisheries productivity, coastal fisheries management, increasing populations, and rising NCDs.

\section{Abbreviations}

BMI: body mass index; NCDs: non communicable diseases; PICO: population, intervention, comparator, outcome; PICT: Pacific Island countries and territories.

\section{Competing interests}

The authors declare that they have no competing interests.

\section{Authors' contributions}

$\mathrm{KC}, \mathrm{QH}$ and JR conceptualised the review, designed the PICO question and developed the search strategy. EG and JR conducted the literature search and summarised the review articles. EG prepared the first draft of the article. All authors contributed to synthesis of the results and editing of the final manuscript. All authors read and approved the final manuscript.

\section{Acknowledgments}

This study was supported by a research grant from the Global Challenges programme at the University of Wollongong.

\section{Author details}

'School of Medicine, University of Wollongong, Wollongong, NSW 2522, Australia. ${ }^{2}$ School of Health and Society, University of Wollongong, Wollongong, NSW 2522, Australia. ${ }^{3}$ Australian National Centre for Ocean Resources and Security (ANCORS), University of Wollongong, Wollongong, NSW 2522, Australia. ${ }^{4}$ Betty and Gordon Moore Center for Science and Oceans, Conservation International, Arlington, VA 22202, USA.

Received: 6 August 2015 Accepted: 14 March 2016

Published online: 24 March 2016

\section{References}

1. Barnett J. Dangerous climate change in the Pacific Islands: food production and food security. Reg Environ Chang. 2011;11 Suppl 1:229-37.

2. Secretariat of the Pacific Community Statistics for Development Division Population and Demographic Indicators Update. 2013. 9 Feb 2015]; Available from: http://www.spc.int/sdd/.

3. Secretariat of the Pacific Community, Pocket Statistical Summary 2013. Noumea, New Caledonia: SPC; 2013.

4. United Nations Conference on Trade and Development. United Nations list of least developed countries. 2013. [cited 201520 April]; Available from: http://unctad.org/en/Pages/ALDC/Least\%20Developed\%20Countrie s/UN-list-of-Least-Developed-Countries.aspx.

5. Popkin BM. Global nutrition dynamics: the world is shifting rapidly toward a diet linked with noncommunicable diseases. Am J Clin Nutr. 2006;84(2):289-98.

6. Snowdon W et al. Processed foods available in the Pacific Islands. Glob Health. 2013:9:1

7. Estime MS, Lutz B, Strobel F. Trade as a structural driver of dietary risk factors for noncommunicable diseases in the Pacific: an analysis of household income and expenditure survey data. Glob Health. 2014;10:48.

8. Thow AM et al. Trade and the nutrition transition: strengthening policy for health in the pacific. Ecol Food Nutr. 2011;50(1):18-42.

9. Taylor $\mathrm{R}$ et al. Dietary intake, exercise, obesity and noncommunicable disease in rural and urban populations of three Pacific Island countries. J Am Coll Nutr. 1992;11(3):283-93.
10. Hodge AM, Dowse GK, Toelupe P. Dramatic increase in the prevalence of obesity in western Samoa over the 13 year period 1978-1991. Int J Obes Relat Metab Disord. 1994;18(6):419-28.

11. Hughes RG, Lawrence MA. Globalisation, food and health in Pacific Island countries. Asia Pac J Clin Nutr. 2005;14(4):298-306.

12. Prentice $\mathrm{AM}$. The emerging epidemic of obesity in developing countries. Int J Epidemiol. 2006;35(1):93-9.

13. Finucane $M M$ et al. National, regional, and global trends in body-mass index since 1980: systematic analysis of health examination surveys and epidemiological studies with 960 country-years and $9 \cdot 1$ million participants. Lancet. 2011:377:557-67.

14. World Health Organisation (WHO). Noncommunicable diseases country profiles 2011. France: WHO global report; 2011.

15. World Health Organisation Representative Office in the South Pacific. Noncommunicable diseases South Pacific situation summary. 2015. [cited 20154 June]; Available from: http://www.wpro.who.int/southpacific/ programmes/healthy_communities/noncommunicable diseases/page/en/.

16. Coyne T. Lifestyle diseases in Pacific communities. Noumea: Secretariat of the Pacific Community; 2000

17. Knowles J. Review of the nutrition situation in fourteen Pacific Island countries: constraints and opportunities. Bangkok: United Nations Children's Fund East Asia and Pacific Office; 2005.

18. Allen L. Anemia and iron deficiency: effects on pregnancy outcome. Am J Clin Nutr. 2000;71:1280S-4S

19. Sachdev HP, Gera T, Nestel P. Effect of iron supplementation on mental and motor development in children: systematic review of randomised controlled trials. Public Health Nutr. 2005;8(2):117-32.

20. Hughes R. The Feasibility of micronutrient (iron) food fortification in Pacific Island countries. Philippines: World Health Organisation Western Pacific Regional Office; 2006.

21. Bosu, W.K., An overview of the nutrition transition in West Africa: implications for non-communicable diseases. Proceedings of the Nutrition Society; 2014

22. Conde WL, Monteiro CA. Nutrition transition and double burden of undernutrition and excess of weight in Brazil. Am J Clin Nutr. 2014;100(6): 1617S-22S.

23. Rivera JA et al. Nutrition transition in Mexico and in other Latin American countries. Nutr Rev. 2004;62(7 II):S149-57.

24. Tzioumis E, Adair LS. Childhood dual burden of under- and over-nutrition in low- and middle-income countries: a critical review. Food Nutr Bull. 2014; 35(2):230-43.

25. Winichagoon P. Transition of maternal and child nutrition in Asia: implications for public health. Curr Opin Clin Nutr Metab Care. 2015;18(3):312-7.

26. Oddo $\mathrm{V}$ et al. Predictors of maternal and child double burden of malnutrition in rural Indonesia and Bangladesh. Am J Clin Nutr. 2012;95(4):951-8.

27. Bell JD et al. Planning the use of fish for food security in the Pacific. Mar Policy. 2009;33(1):64-76.

28. Béné $C$ et al. Feeding 9 billion by 2050 - putting fish back on the menu. Food Security. 2015;7(2):261-74.

29. Kawarazuka N, Bene $\mathrm{C}$. The potential role of small fish species in improving micronutrient deficiencies in developing countries: building evidence. Public Health Nutr. 2011:14(1):1927-38.

30. Kawarazuka N. The contribution of fish intake, aquaculture, and small-scale fisheries to improving nutrition: a literature review, in The WorldFish center working paper No.2106. Malaysia: The World Fish Center; 2010.

31. Bell JD et al. Diversifying the use of tuna to improve food security and public health in Pacific Island countries and territories. Mar Policy. 2015;51:584-91.

32. Moher $\mathrm{D}$ et al. Preferred reporting items for systematic reviews and metaanalyses: the PRISMA statement. Ann Intern Med. 2009;151(4):264-9. w64.

33. Clero E et al. Dietary patterns, goitrogenic food, and thyroid cancer: a casecontrol study in French Polynesia. Nutr Cancer. 2012;64(7):929-36.

34. Vengiau $\mathrm{G}$ et al. Associations of socioeconomic status with diet and physical activity in migrant Bougainvilleans in Port Moresby, Papua New Guinea. Ecol Food Nutr. 2014;53(5):471-83.

35. Vengiau $\mathrm{G}$ et al. Diet and physical activity among migrant Bougainvilleans in Port Moresby, Papua New Guinea: association with anthropometric measures and blood pressure. Am J Hum Biol. 2012;24(5):716-8.

36. Clero $\mathrm{E}$ et al. Dietary iodine and thyroid cancer risk in French Polynesia: a case-control study. Thyroid. 2012:22(4):422-9.

37. Corsi A et al. A participatory assessment of dietary patterns and food behavior in Pohnpei, Federated States of Micronesia. Asia Pac J Clin Nutr. 2008;17(2):309-16. 
38. Dewailly E et al. High fish consumption in French Polynesia and prenatal exposure to metals and nutrients. Asia Pac J Clin Nutr. 2008;17(3):461-70.

39. Li M et al. lodine nutritional status of children on the island of Tanna, Republic of Vanuatu. Public Health Nutr. 2009;12(9):1512-8.

40. Phongsavan $P$ et al. Health behaviour and lifestyle of Pacific youth surveys: a resource for capacity building. Health Promot Int. 2005;20(3):238-48.

41. Mertz $\mathrm{O}$ et al. Sustainable land use in Tikopia: food production and consumption in an isolated agricultural system. Singap J Trop Geogr. 2010;31(1):10-26.

42. Turner RA et al. Declining reliance on marine resources in remote South Pacific societies: ecological versus socio-economic drivers. Coral Reefs. 2007; 26(4):997-1008.

43. Kronen M, Bender A. Assessing marine resource exploitation in Lofanga, Tonga: one case study - two approaches. Hum Ecol. 2007;35(2):195-207.

44. Guillemot $N$ et al. Characterization and management of informal fisheries confronted with socio-economic changes in New Caledonia (South Pacific). Fish Res. 2009;98(1-3):51-61.

45. Kuster C, Vuki VC, Zann LP. Long-term trends in subsistence fishing patterns and coral reef fisheries yield from a remote Fijian island. Fish Res. 2005;76(2): 221-8.

46. Dancause $\mathrm{KN}$ et al. Behavioral changes associated with economic development in the South Pacific: health transition in Vanuatu. Am J Hum Biol. 2011;23(3):366-76.

47. Craig P, Green A, Tuilagi F. Subsistence harvest of coral reef resources in the outer islands of American Samoa: modern, historic and prehistoric catches. Fish Res. 2008;89(3):230-40.

48. Léopold M, Ferraris J, Labrosse P. Assessment of the reliability of fish consumption as an indicator of reef fish catches in small Pacific Islands: the example of Ouvea Island in New Caledonia. Aquat Living Resour. 2004;17(2): 119-27.

49. Smith BJ et al. Body mass index, physical activity and dietary behaviours among adolescents in the Kingdom of Tonga. Public Health Nutr. 2007; 10(2):137-44.

50. Labrosse P, Ferraris J, Letourneur Y. Assessing the sustainability of subsistence fisheries in the Pacific: the use of data on fish consumption. Ocean Coast Manag. 2006:49(3-4):203-21.

51. Pobocik RS, Trager A, Monson LM. Dietary patterns and food choices of a population sample of adults on Guam. Asia Pac J Clin Nutr. 2008; 17(1):94-100.

52. Aswani S, Furusawa T. Do marine protected areas affect human nutrition and health? A comparison between villages in Roviana, Solomon Islands. Coast Manag. 2007;35(5):545-65.

53. Konishi $\mathrm{S}$ et al. Energy and nutrient intake of Tongan adults estimated by 24-hour recall: the importance of local food items. Ecol Food Nutr. 2011; 50(4):337-50.

54. Hedges R, Rush E, Aalbersberg W. Correspondence between human diet, body composition and stable isotopic composition of hair and breath in Fijian villagers. Isot Environ Health Stud. 2009;45(1):1-17.

55. Englberger $L$ et al. Vitamin $A$ intake and factors influencing it amongst children and caretakers in Kosrae, Micronesia. Ecol Food Nutr. 2005;44(4): 307-38.

56. Latham MC. Human nutrition in the developing world. Rome: Food and Agriculture Organisation of the United Nations; 1997.

57. Van der Heijden P. Sources of animal protein in meals of the population of the Sepik-Ramu catchment. Sci New Guinea. 2006;28(1-3):3-8.

58. DiBello JR et al. Dietary patterns are associated with metabolic syndrome in adult Samoans. J Nutr. 2009;139(10):1933-43.

59. Dancause KN et al. Behavioral risk factors for obesity during health transition in Vanuatu, south pacific. Obesity. 2013;21(1):e98-e104.

60. O'Garra T. Economic valuation of a traditional fishing ground on the coral coast in Fiji. Ocean Coast Manag. 2012;56:44-55.

61. Middlebrook R, Williamson JE. Social attitudes towards marine resource management in two Fijian villages. Ecol Manag Restor. 2006;7(2):144-7.

62. Walker BLE, Robinson MA. Economic development, marine protected areas and gendered access to fishing resources in a Polynesian lagoon. Gender, Place Cult. 2009;16(4):467-84

63. Cinner JE, Marnane MJ, McClanahan TR. Conservation and community benefits from traditional coral reef management at Ahus Island, Papua New Guinea. Conserv Biol. 2005;19(6):1714-23.

64. Albert JA et al. The contribution of nearshore fish aggregating devices (FADs) to food security and livelihoods in Solomon Islands. PLoS One. 2014; 9(12):e115386.
65. Albert $\mathrm{S}$ et al. Indicators of coral reef ecosystem recovery following reduction in logging and implementation of community-based management schemes in the Solomon Islands. Pac Conserv Biol. 2014;20(1):75-85.

66. FAO Fisheries and Aquaculture Department. The state of world fisheries and aquaculture 2012. Rome: Food and Agriculutre Organization of the United Nations; 2012

67. Cinner J. Socioeconomic factors influencing customary marine tenure in the Indo-Pacific. Ecol Soc. 2005;10:1.

68. Keeble R, Keeble J. Nutritional study of the 1-4 year old population of the Lower Jimi Valley, Western Highlands Province, Papua New Guinea. P N G Med J. 2006:49(3-4):156-61.

69. Aipit S, Aipit J, Laman M. Malnutrition: a neglected but leading cause of child deaths in Papua New Guinea. Lancet Global Health. 2014;2(10):e568.

70. Sulu RJ et al. Livelihoods and fisheries governance in a contemporary Pacific Island setting. PLoS One. 2015;10(11):e0143516.

71. Food and Agricultural Organisation of the United Nations. Nutrition country profiles - Fiji. Rome: Food and Agricultural Organisation of the United Nations; 2003

72. Food and Agricultural Organisation of the United Nations. Nutrition country profiles - Papua New Guinea. Rome: Food and Agricultural Organisation of the United Nations; 2003. Available at: ftp://ftp.fao.org/es/esn/nutrition/ncp/ pngmap.pdf. Accessed 17 Mar 2016.

73. Wook JC, Jeongseon K. Factors and the risk of thyroid cancer: a review. Clin Nutr Res. 2014;3(2):75-88.

74. Englberger $L$ et al. Vitamin a deficiency among children — federated States of Micronesia, 2000. MMWR Weekly. 2001;50(24):509-12.

75. Government of Kiribati and United Nations Children's Fund. Kiribati - a situation analysis of children, women and youth. Fiji: United Nations Children's Fund Pacific Office; 2005.

76. Palafox NA et al. Relationship of vitamin a deficiency, iron deficiency, and inflammation to anemia among preschool children in the Republic of the Marshall Islands. Eur J Clin Nutr. 2004;58(10):1396-401.

77. Christoforou A et al. Progress on salt reduction in the Pacific Islands: from strategies to action. Heart Lung Circ. 2015;24(5):503-9.

78. Webster $\mathrm{J}$ et al. Costeffectiveness of reducing salt intake in the Pacific Islands: protocol for a before and after intervention study. BMC Public Health. 2014;14:107-14.

79. Keighley ED, McGarvey ST, Quested C, McCuddin C, Viali S, Maga U. Nutrition and health in modernizing Samoans: temporal trends and adaptive perspectives. In: Ohtsuka R, Ulijaszek SJ, editors. Health change in the Asia-Pacific: biocultural and epidemiological approaches. Cambridge (UK): Cambridge University Press; 2007. p. 147-91.

80. Cassels S. Overweight in the pacific: links between foreign dependence, global food trade, and obesity in the federated States of Micronesia. Glob Health. 2006;2:10

81. Kronen M. Fishing for fortunes? A socio-economic assessment of Tonga's artisanal fisheries. Fish Res. 2004;70(1):121-34.

82. Dignan $\mathrm{C}$ et al. The Pacific Islands food composition tables. 2nd ed. Rome: Food and Agricultural Organisation of the United Nations; 2004.

83. Thaman RR. Deterioration of traditional food systems, increasing malnutrition and food dependency in the Pacific Islands. J Food Nutri. 1982; 39(3):109-21.

84. Malcolm S. Nutrition investigations in the New Hebrides. Noumea, New Caledonia: Report On Research Conducted In the New Hebrides During 1951 Under Commission Project H.2-H.5; 1952. p. 55.

85. Coyne T, Badcock J, Taylor R. The effect of urbanisation and western diet on the health of Pacific Island populations. Suva, Fiji: South Pacific Commission; 1984

86. World Health Organisation. Diet, food supply and obesity in the Pacific. Geneva: World Health Organization Regional Office for the Western Pacific; 2003.

87. Carlot-Tary M. 1998 Vanuatu non-communicable disease survey report. Noumea: Secretariat of the Pacific Community; 2000.

88. Kronen $\mathrm{M}$ et al. Socio-economic drivers and indicators for artisanal coastal fisheries in Pacific Island countries and territories and their use for fisheries management strategies. Mar Policy. 2010;34(6):1135-43.

89. Pinca, S., et al., Regional assessment report: profiles and results from survey work at 63 sites across 17 Pacific Island Countries and Territories. Noumea, New Caledonia: Pacific Regional Oceanic and Coastal Fisheries Development Programme (PROCFish/C/CoFish). 2010.

90. Food Secure Pacific Working Group \& Pacific Food Summit, Towards a food secure Pacific. Framework for action on food security in the Pacific. Vanuatu: SPC; 2010. 
91. Englberger $L$ et al. Pohnpei, Federated States of Micronesia case study in a global health project documents its local food resources and successfully promotes local food for health. Pac Health Dialog. 2010;16(1):129-36.

92. Food and Agriculture Organisation of the United Nations (FAO). Nutrition education for the public. Discussion papers of the FAO expert consultation. United Nations. FAO Food Nutr Pap. 1997;62:1-212.

93. Anon A. new song for coastal fisheries - pathways to change: The Noumea strategy. SPC Fisheries Newsletter. 2015;146:37-46.

94. Vanuatu National Statistics Office. 2015. Feb 23 2015]; Available from: http://www.vnso.gov.vu.

95. United Nations Department of Economic Affairs. World Population Prospects: The 2012 revision. 2013. [cited 201510 Feb]; Available from: http://esa.un.org/wpp/Excel-Data/population.htm.

96. Vanuatu National Statistics Office and Secretariat of the Pacific Community, Vanuatu Demographic and Health Survey 2013. Noumea: SPC; 2014.

97. Vanuatu National Statistics Office, Main Report on the Household Income and Expenditure Survey 2006. Port Vila: Vanuatu National Statistics Office; 2006.

98. World Health Organisation. Global prevalence of vitamin A deficiency in populations at risk 1995-2005. WHO Global Database on Vitamin A Deficiency. Geneva: World Health Organisation; 2009.

99. World Health Organisation, Global Health Observatory Data Repository: Raised Blood Pressure. Geneva, Switzerland: World Health Organisation; 2008.

100. World Health Organisation, Global Health Observatory Data Repository: Raised Fasting Blood Glucose. Geneva, Switzerland: World Health Organisation; 2014

101. World Health Organisation, Global Health Observatory Data Repository: Raised Total Cholesterol. Geneva, Switzerland: World Health Organisation: 2008.

102. FAOSTAT. Vanuatu Country Profile. 2011. [cited 2015 9 Feb]; Available from: http://faostat.fao.org/site/368/default.aspx\#ancor.

103. Food and Agriculture Organisation of the United Nations. Country Profile: Food Security Indicators. Rome: FAO; 2009. Available from: http://www.fao. org/fileadmin/templates/ess/documents/food_security_statistics/country_ profiles/eng/Vanuatu_E.pdf. Accessed 17 Mar 2016.

104. Gillett R, Lightfoot C. The Contribution of Fisheries to the Economies of Pacific Island Countries. Manila: Asian Development Bank; 2002.

105. Vanuatu National Statistics Office, 2009 National Population and Housing Census. Port Vila: Vanuatu National Statistics Office; 2009.

106. World Health Organisation Western Pacific Region, Western Pacific Country Health Information Profiles. Geneva Switzerland: World Health Organization; 2009. p. 102-7.

107. UN Inter-agency Group for Child Mortality Estimation (IGME). Country Specific Under-Five Mortality Rate. 2014. [cited 201510 Feb]; Available from: http://data.unicef.org./child-mortality/under-five.

108. Kiribati National Statistics Office and the Secretariat of the Pacific Community (SPC), Kiribati Demographic and Health Survey 2009. Noumea: SPC; 2010.

109. Kiribati National Statistics Office, Analytical Report on the 2006 Kiribati Household Income and Expenditure Survey. Kiribati: Kiribati National Statistics Office; 2006.

110. World Health Organisation, Global Health Observatory Data Repository: Overweight/Obesity. Geneva, Switzerland: World Health Organisation; 2014.

111. FAOSTAT. Kiritbati Country Profile. 2011. [cited 20159 Feb]; Available from: http://faostat.fao.org/site/368/default.aspx\#ancor.

112. World Health Organization Nutrition Landscape Information System (NLiS) lodized Salt Consumption.1998. [cited 201511 Feb]; Available from: http:// apps.who.int/nutrition/landscape/report.aspx?iso=kir\&print=1.

113. Kiribati National Statistics Office, Report on the Kiribati 2010 Census of Population and Housing. Kiribati: Kiribati National Statistics Office; 2010.

114. Tonga Department of Statistics and the Secretariat of the Pacific Community, Tonga 2011 Census of Population and Housing, Volume 2: Analytical Report. Noumea: SPC; 2014.

115. Tonga Department of Statistics. Health Statistics. 2014. [cited 2015 Feb 10] Available from: http://www.spc.int/prism/tonga/index.php?option=com_ content\&view $=$ article\&id $=27 \& \mid$ temid $=31$

116. Tonga Department of Statistics Tonga Ministry of Health Secretariat of the Pacific Community and United Nations Population Fund, Tonga Demographic and Health Survey, 2012. Noumea: SPC; 2013.

117. Kingdom of Tonga Department of Statistics, Household Income and Expendicture Survey 2009. Nuku'alofa: Kingdom of Tonga Statistics Department; 2010
118. Food and Agriculture Organisation of the United Nations. Fishery and aquaculture statistics: food balance sheets. Rome: FAO Yearbook of Fishery and Aquaculture Statistics; 2009. p. 55-68.

119. Ministry of Agriculture and Forestry and Statistics Department, Tonga Agricultural Census. Nuku'alofa: Department of Statistics; 2002.

120. Tonga Department of Statistics, Report on the Tonga Labour Force Survey 2003. Nuku 'alofa: Government of Tonga; 2004

\section{Submit your next manuscript to BioMed Central and we will help you at every step:}

- We accept pre-submission inquiries

- Our selector tool helps you to find the most relevant journal

- We provide round the clock customer support

- Convenient online submission

- Thorough peer review

- Inclusion in PubMed and all major indexing services

- Maximum visibility for your research

Submit your manuscript at www.biomedcentral.com/submit
) Biomed Central 